\title{
A Comparative Study on Cooling Period Thermal Comfort Assessment in Modern Open Office Landscape in Estonia
}

\author{
Martin Kiil ${ }^{1, *}$, Raimo Simson ${ }^{1}{ }^{\mathbb{D}}$, Martin Thalfeldt ${ }^{1}$ and Jarek Kurnitski ${ }^{1,2}$ \\ 1 Department of Civil Engineering and Architecture, Tallinn University of Technology, Ehitajate tee 5, \\ 19086 Tallinn, Estonia; raimo.simson@taltech.ee (R.S.); martin.thalfeldt@taltech.ee (M.T.); \\ jarek.kurnitski@taltech.ee (J.K.) \\ 2 School of Engineering, Aalto University, Otakaari 4, 02150 Espoo, Finland \\ * Correspondence: martin.kiil@taltech.ee
}

Received: 22 December 2019; Accepted: 19 January 2020; Published: 23 January 2020

\begin{abstract}
Local thermal comfort and draught rate has been studied widely. There has been more meaningful research performed in controlled boundary condition situations than in actual work environments involving occupants. Thermal comfort conditions in office buildings in Estonia have been barely investigated in the past. In this paper, the results of thermal comfort and draught rate assessment in five office buildings in Tallinn are presented and discussed. Studied office landscapes vary in heating, ventilation and cooling system parameters, room units, and elements. All sample buildings were less than six years old, equipped with dedicated outdoor air ventilation system and room conditioning units. The on-site measurements consisted of thermal comfort and draught rate assessment with indoor climate questionnaire. The purpose of the survey is to assess the correspondence between heating, ventilation and cooling system design, and the actual situation. Results show, whether and in what extent the standard-based criteria for thermal comfort is suitable for actual usage of the occupants. Preferring one room conditioning unit type or system may not guarantee better thermal environment without draught. Although some heating, ventilation and cooling systems observed in this study should create the prerequisites for ensuring more comfort, results show that this is not the case for all buildings in this study.
\end{abstract}

Keywords: thermal comfort; draught; cooling period; open office

\section{Introduction}

Modern low energy office buildings require energy efficient heating, ventilation, and air conditioning (HVAC) systems which can provide comfortable and healthy indoor environment. In temperate climate countries, mechanical ventilation and active cooling systems are common practice in such buildings. However, mechanical HVAC systems do not always provide satisfactory thermal conditions [1]. It is important to properly apply control strategies, design and install room cooling units and ventilation supply air elements, as well as to operate and maintain the systems to provide comfortable indoor climate without temperature fluctuations and draught risk in the cooling season [2-8]. Office plans, in terms of occupant positions and density, can be very different from initial design and vary significantly, resulting in changing conditions and dynamic settings which makes it difficult to design the systems adequately to ensure stable thermal environment. Open office layout design is used commonly in most office buildings mainly to allow flexibility in workspaces allocation [9]. This creates a difficult task for HVAC systems design, requiring careful planning to assure adequate conditions in the occupied zone in different layout cases. 
As occupant satisfaction with thermal environment is dependent on many factors, such as gender, age, health, activity, mood, and other physiological and psychological factors, assessing thermal comfort (TC) based on temperature and air movement measurements is usually not sufficient for adequate estimation [6,10-13]. Thus, evaluation by questioning the occupants is usually also needed to specify the problems and get a comprehensive overview of the TC situation. Studies on office workers thermal sensation have shown that the predicted TC and actual sensation can differ significantly $[12,14,15]$. For example, gender specific analysis indicates higher dissatisfaction rates for female occupants [11,16-19]. Recent research has widely focused on individual perception of TC [20-22], developed methods to analyze the preferences for TC using machine learning algorithms $[23,24]$ and adapt systems to provide preferable personal comfort by implementing Personalized Comfort Systems [20-22,25]. Utilization of such systems in buildings requires paradigm shifts in occupant interaction with HVAC systems as well as system design practices, integration of advanced controls and information technologies solutions [26,27].

In addition to the individual preferences and system specific aspects influencing thermal comfort (TC), there are many building related design factors that can affect the performance of HVAC systems and in turn influence the thermal environment. Of these factors, façade design, namely window sizes, layout, and glazing parameters, can have large impact on cooling load as well as radiant temperature asymmetry and thus major influence on the overall thermal conditions in the office [28,29]. Thalfeldt et al. [28] showed the importance of façade design by analyzing the effect on office buildings energy efficiency and cooling load in cold climate countries. Window-to-wall ratio (WWR) of 0.25 was found optimal for triple glazing window solutions. Larger glazing results in higher cooling loads and increase the need for larger room cooling units, higher cooled airflow rates or lower supply air temperatures to maintain the room temperature. The latter factors also increase the risk of draught in occupied spaces. In several studies, draught rate $(D R)$ has been identified as the main cause of discomfort even if other thermal environment factors are at satisfactory levels $[6,15,29,30]$.

Depending mainly on the cooling load, cooling plant solution, and interior design, different water based room cooling solutions are used in offices, which can be classified by supply water temperature as low temperature room cooling units e.g., fan coil units and high temperature units, such as thermally active building systems (TABS), passive cooling beams, or active cooling beams, combined with ventilation supply air terminals [31,32]. In low energy buildings, high temperature cooling is usually preferred to achieve higher energy efficiency for cooled water production by cooling plants [32]. The performance of these systems is extensively analyzed in various recent studies. Most of the research is based on either computer simulations, mainly computational fluid dynamics (CFD) studies or studies conducted in controlled laboratory environments [33-47]. The research in real office settings is mainly focused on buildings located in warm and hot climate countries, dominated by cooling need [48-51]. To the knowledge of the authors, only few extensive studies have been carried out in cold and temperate climates and in low energy buildings. In Germany, Pfafferott, Herkel, Kalz, and Zeuschner [14] have conducted research on summertime TC in 12 low energy office buildings which are passively cooled with local heat sink based TABS. Results showed, that $41 \%$ of occupants were dissatisfied with thermal environment in summer, but assessment, according to the standard CEN EN 15251 [52], showed measured indoor temperature-based classification relative to the indoor climate category I (highest) and II, indicating a gap between perceived and assessed TC conditions and the need for more detailed comfort assessment. Hens [15] investigated TC in two office buildings in Belgium cooled with active chilled beams and air-cooling systems. He found that the Fanger [53] predicted mean vote $(P M V)$ /predicted percentage dissatisfied $(P P D)$ curve underestimated the actual number of dissatisfied occupants and that standards should not be considered as absolute references. It was also concluded that one should be very careful when interpreting the results of TC studies.

The theoretical knowledge involved or access to expert engineers during office building design is feasible and implemented in practice in Estonia. However, the volatile quality of different parts of the design, building phase simplifications with budget cuts and the contradiction between the 
initial task and the actual situation leads to a risk of an outcome failure regarding TC for the occupant. In the Estonian construction market, great emphasis is given on diplomas, professional certificates, software for both building information modeling (BIM), and product selection programs integrating BIM solutions in the building process. In reality, during the construction process the HVAC designer and after the warranty period, the constructor retreat. Therefore, in a short period of time during the design a huge effort is invested in the project definition, while after the realization phase much of the expert advice is ignored. Otherwise, complaints regarding draught or room temperature were not topical issues. In Estonia as well, in-depth research on cooling season TC and occupant satisfaction is practically non-existent, a few studies in office buildings have been conducted with the main focus on heating season performance and mostly aimed towards energy efficiency analysis. The conducted studies indicate problems and dissatisfaction with thermal environment but lack the detail to specify the causes and details of occupants' thermal conditions and HVAC systems performance in terms of room equipment.

Regardless of the design and performance of the HVAC systems installed in actual open offices, the hypothesis of this study proposes that high proportion of occupants are dissatisfied with the TC conditions. The goal of this study is to determine, whether the thermal sensation dissatisfaction of the occupants in modern office spaces is verifiable and in accordance with the valid standard criteria. This paper aims to fill the gap of summer TC assessment by extensive field studies and thorough occupant survey in modern office buildings in Estonia, a temperate climate country. We have investigated four recently constructed and one reconstructed office buildings with open plan office layouts designed with different ventilation and cooling solutions, including mixing and displacement ventilation, TABS, radiant cooling panels, fan coil units, and active cooling beams. The on-site measurements conducted in the offices consist of high resolution and accuracy temperature and air velocity measurements with $D R$ and TC calculations, which are described in the following chapter.

\section{Methods}

The flow chart of research methodology is shown in Figure 1. Section of methods is divided between description of reference objects, measurement set-up and equipment specifications, data analysis, and indoor climate questionnaire (ICQ). We used standard-based [52,54,55] methods in this study to measure and calculate TC parameters and to perform an online ICQ survey. The TC measuring probe and tripod mobile and flexible kit set [56] we used was designed for research and development purposes.

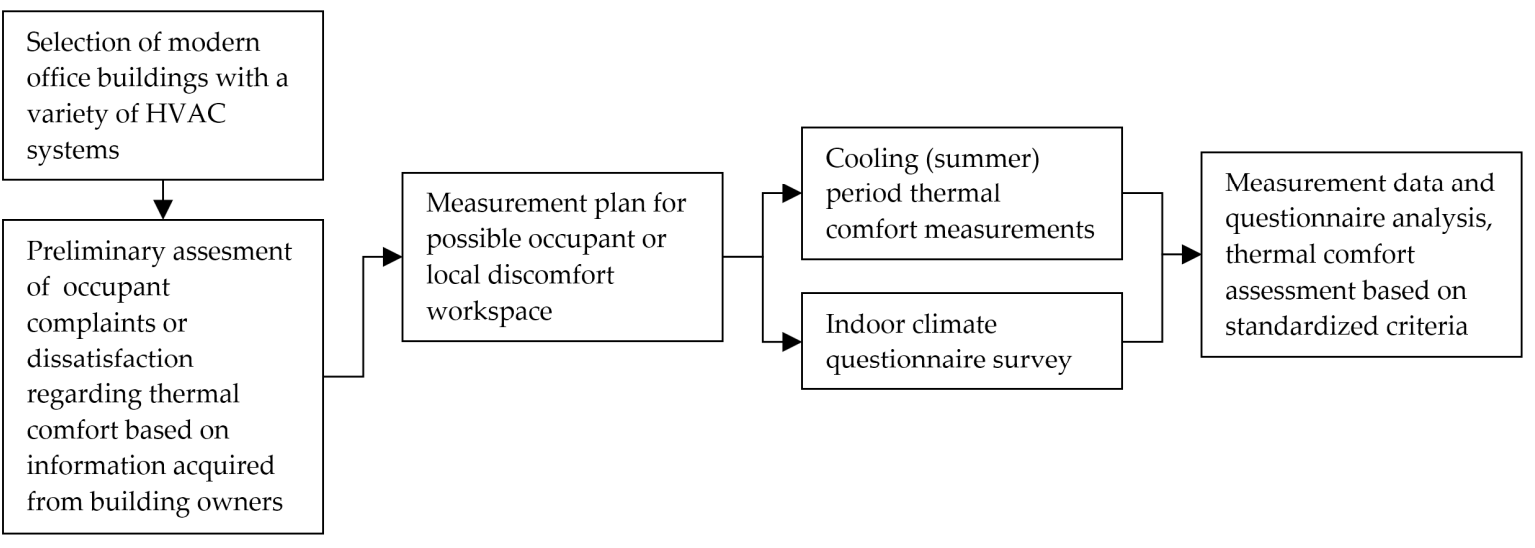

Figure 1. Flow chart of research methodology.

\subsection{Reference Objects}

General information regarding reference objects are provided in Table 1. The scope and range of measurement points with main building envelope characteristics, such as thermal transmittance for 
main surfaces, such as walls, windows, floors on ground and roofs are listed with specific heat loss of external envelopes and window-to-wall ratios.

Table 1. General building information of reference objects.

\begin{tabular}{|c|c|c|c|c|c|}
\hline Bldg & Year of Constr. & $\begin{array}{l}\text { Net Floor Area } \\
\left(\mathrm{m}^{2}\right) / \text { appr. Total } \\
\text { Measured Area }(\%)\end{array}$ & $\begin{array}{l}\text { No of Floors/ } \\
\text { No of Measured } \\
\text { Floors }\end{array}$ & $\begin{array}{l}\text { Thermal Transmittance } \\
\qquad W /\left(m^{2} \times K\right)\end{array}$ & $\begin{array}{c}\text { Specific Heat Loss of External Envelopes } \\
\left.\text { W/(m }{ }^{2} \times \mathrm{K}\right) / \text { Window-to-Wall Ratio/Glazing } \\
g \text { Value }\end{array}$ \\
\hline A & 2015 & $10,800 / 30$ & $13 / 4$ & $\begin{array}{l}U_{\text {window }} 0.80 / U_{\text {wall }} 0.18 \\
U_{\text {roof }} 0.09 / U_{\text {floor }} 0.14\end{array}$ & $\begin{array}{c}H / A 0.50 \\
W W R 0.69 \\
\quad g 0.25\end{array}$ \\
\hline B & 2018 & $7000 / 20$ & $5 / 3$ & $\begin{array}{c}U_{\text {window }} 0.83 / U_{\text {wall }} 0.12 \\
U_{\text {roof }} 0.09 / U_{\text {floor }} 0.13^{*} \\
\left({ }^{*} \text { above ambient air }\right)\end{array}$ & $\begin{array}{c}\text { H/A } 0.31 \\
W W R 0.59 \\
\quad g 0.24\end{array}$ \\
\hline $\mathrm{C}$ & 2017 & $18,900 / 10$ & $14 / 2$ & $\begin{array}{l}U_{\text {window }} 0.65 / U_{\text {wall }} 0.10 \\
U_{\text {roof }} 0.10 / U_{\text {floor }} 0.15\end{array}$ & $\begin{array}{c}\text { H/A } 0.30 \\
\text { WWR } 0.38 \\
\quad g 0.30\end{array}$ \\
\hline $\mathrm{D}$ & 2018 & $\begin{array}{c}\text { 13,900/100 (available } \\
\text { office space) }\end{array}$ & $2 / 2$ & $\begin{array}{l}U_{\text {window }} 1.0 / U_{\text {wall }} 0.15 \\
U_{\text {roof }} 0.14 / \underline{U_{\text {floor }}}<0.15\end{array}$ & $\begin{array}{c}H / A<0.20 \\
W W R<0.25 \\
g 0.30\end{array}$ \\
\hline E & $\begin{array}{l}\text { Reconstr, } 2014 \\
\quad(1982)\end{array}$ & $5300 / 20$ & $6 / 1$ & $\begin{array}{c}U_{\text {window }}>1.2 / U_{\text {wall }}>0.25 \\
U_{\text {roof }} \mathrm{N} / \mathrm{A} / U_{\text {floor }} \mathrm{N} / \mathrm{A}\end{array}$ & $\begin{array}{l}H / A>0.50 \\
W W R 0.90 \\
\quad g 0.40\end{array}$ \\
\hline
\end{tabular}

In Buildings A, B, C, and D, measurements were also taken on the highest floor and in Buildings $\mathrm{B}$ and $\mathrm{D}$ on the lowest floor. The temperature of slabs was considered to be close to $t_{i}$ and therefore the impact on operative temperature was not accounted for, as heat transmission through the building envelope in such low energy buildings is negligible compared to the heat gains through glazed surfaces and have little effect on TC. A variety of HVAC systems was involved in measurements zones (Table 2) including new and innovative solutions in the Estonian construction market.

Table 2. Heating, ventilation, and air conditioning room design solutions of reference objects.

\begin{tabular}{|c|c|c|c|}
\hline Bldg. & Heating & Ventilation & Cooling \\
\hline A & $\begin{array}{l}\text { Water-based convectors (height } 300 \mathrm{~mm} \text {, length } \\
700-1800 \mathrm{~mm} \text { ) below the windowsill. Installed } \\
\text { room unit heating power } 18 \mathrm{~W} / \mathrm{m}^{2} \text {. }\end{array}$ & $\begin{array}{l}\text { Mixing ventilation } 1.41 /\left(\mathrm{s} \times \mathrm{m}^{2}\right) \text { using active } \\
\text { exposed chilled beams (effective length } \\
2700-3300 \mathrm{~mm} \text { ) mounted in the open ceiling } \\
\text { (height } 2.75 \mathrm{~m}) \text { for supply and circular valves } \\
(\varnothing 125 \mathrm{~mm}) \text { for extract air (height } 2.7 \mathrm{~m}) \text {. }\end{array}$ & $\begin{array}{l}\text { Active exposed chilled beams } \\
\text { (effective length } 2700-3300 \mathrm{~mm} \text { ) } \\
\text { mounted in the open ceiling (height } \\
2.75 \mathrm{~m} \text { ). Installed room unit sensible } \\
\text { cooling power } 52 \mathrm{~W} / \mathrm{m}^{2} \text {. }\end{array}$ \\
\hline B & $\begin{array}{l}\text { Thermally active building system (slab, room } \\
\text { height } 3.0 \mathrm{~m} \text { ). Installed heating power } 43 \mathrm{~W} / \mathrm{m}^{2} \text {. }\end{array}$ & $\begin{array}{l}\text { Displacement ventilation } 1.4 \mathrm{l} /\left(\mathrm{s} \times \mathrm{m}^{2} \text { ) }\right. \\
\text { including duct diffusers (Ø } 160-315 \mathrm{~mm} \text {, nozzle } \\
\text { angle } 120-180^{\circ} \mathrm{C} \text { ) for supply (height } 2.7-2.8 \mathrm{~m} \text { ), } \\
\text { mounted in the open ceiling to the perimeter of } \\
\text { rooms. Wall and ceiling grilles with plenum } \\
\text { box serving extract air (height } 2.8 \mathrm{~m} \text { on cornice, } \\
2.6 \mathrm{~m} \text { for ribbed suspended ceiling). }\end{array}$ & $\begin{array}{l}\text { Thermally active building system } \\
\text { (slab, room height } 3.0 \mathrm{~m} \text { ). Installed } \\
\text { sensible cooling power } 41 \mathrm{~W} / \mathrm{m}^{2} \text {. }\end{array}$ \\
\hline $\mathrm{C}$ & $\begin{array}{l}\text { 4-pipe active ceiling integrated chilled beams } \\
\text { (effective length 900-1500 mm) mounted in } \\
\text { suspended ceiling (height } 2.7 \mathrm{~m} \text { ). Installed room } \\
\text { unit heating power } 17 \mathrm{~W} / \mathrm{m}^{2} .\end{array}$ & $\begin{array}{l}\text { Mixing ventilation } 1.7 \mathrm{l} /\left(\mathrm{s} \times \mathrm{m}^{2}\right) \text { using 4-pipe } \\
\text { ceiling integrated chilled beams (effective } \\
\text { length } 900-1500 \mathrm{~mm} \text { ) for supply air and circular } \\
\text { valves }(\varnothing 100 \mathrm{~mm} \text { ) for extract air (height } 2.7 \mathrm{~m}) \text {. }\end{array}$ & $\begin{array}{c}\text { 4-pipe active ceiling integrated chilled } \\
\text { beams (effective length } 900-1500 \mathrm{~mm} \text { ) } \\
\text { mounted in suspended ceiling (height } \\
2.7 \mathrm{~m} \text { ). Installed room unit sensible } \\
\text { cooling power } 46 \mathrm{~W} / \mathrm{m}^{2} .\end{array}$ \\
\hline E & $\begin{array}{l}\text { Electrical convectors (height } 200 \mathrm{~mm} \text {, length } \\
1500 \mathrm{~mm} \text { ) in front of windows. Installed room } \\
\text { unit heating power } 60 \mathrm{~W} / \mathrm{m}^{2} \text {. }\end{array}$ & $\begin{array}{l}\text { Mixing ventilation } 1.31 /\left(\mathrm{s} \times \mathrm{m}^{2}\right) \text { with circular } \\
\text { supply and extract air valves }(\varnothing 160-250 \mathrm{~mm} \text { ) } \\
\text { mounted in the suspended ceiling } \\
\text { (height } 2.5-2.7 \mathrm{~m})\end{array}$ & $\begin{array}{l}\text { Multi-split fan coil units (without } \\
\text { heating function) mounted in the } \\
\text { suspended ceiling (height } 2.7 \mathrm{~m} \text { ). } \\
\text { Installed total cooling power } 78 \mathrm{~W} / \mathrm{m}^{2} \\
\text { (Ventilation supply air is not chilled) }\end{array}$ \\
\hline
\end{tabular}

Ø: diameter of air diffuser connection duct.

The buildings involved in this study were chosen from a range of modern office spaces in Tallinn. First criteria for reference objects was the correspondence with the Estonian energy efficiency regulations, which were first set in 2007 [57]. This created the prerequisites for new buildings and 
HVAC systems criteria, such as envelope related parameters, such as air tightness, external wall insulation thickness, window glazing solutions, and HVAC system parameters, e.g., effectiveness of room units and energy sources, heat recovery effectiveness, specific fan power of ventilation units etc. Buildings A and B have high temperature heating systems and district heating. Building B is using low temperature heating and a ground source heat pump, Building D has high temperature heating water produced and a gas boiler and electrical heating convectors are installed in Building E. All of the studied buildings are equipped with dedicated outdoor air ventilation systems with heat recovery. Ventilation air distribution methods were classified as mixing ventilation, except for Building B, where supply air systems were built in a way to support displacement ventilation method. Buildings $A$ and $\mathrm{C}$ were using active chilled beams for supply air distribution. Buildings $\mathrm{A}, \mathrm{C}$, and D are built with chillers to supply the cooling system. In all Buildings, except for E, high temperature cooling is used in room conditioning units as supply air is dehumidified in the air handling units. Multi-split fan coil units with refrigerant without the option of heating function were in operation in Building E. Room conditioning units in Buildings $C$ and $D$, including the Building B with thermally active buildings system, operated both for heating and cooling purposes.

\subsection{Measurement Equipment}

Experimental measurements in this study were carried out with a TC measurement system Dantec Dynamics ComfortSense [56]. The system is designed for high quality multi-point measurements of $v_{a}$, $t_{i}, R H$, and $t_{0}$. The set is equipped with software, what allows easy setup for measuring sequence and positions giving researchers a comprehensive overview if the measured data. Measurement equipment probe data is described in Table 3.

Table 3. Specifications of measuring equipment [56].

\begin{tabular}{|c|c|c|c|}
\hline & 54T33 Draft Probe & $\begin{array}{l}\text { 54T37 Relative } \\
\text { Humidity Probe }\end{array}$ & $\begin{array}{l}\text { 54T38 Operative } \\
\text { Temperature Probe }\end{array}$ \\
\hline \multicolumn{4}{|l|}{ Image } \\
\hline Range & $\begin{array}{c}0.05-5 \mathrm{~m} / \mathrm{s} \\
-20^{\circ} \mathrm{C} \text { to }+80^{\circ} \mathrm{C}\end{array}$ & $0-100 \%$ & 0 to $+45^{\circ} \mathrm{C}$ \\
\hline Accuracy & $\begin{array}{c} \pm 0.02 \mathrm{~m} / \mathrm{s} \\
\pm 0.2 \mathrm{~K}\end{array}$ & $+1.5 \%$ & $\pm 0.2 \mathrm{~K}$ \\
\hline
\end{tabular}

The set is mounted on a tripod including five draft probes, one humidity and one $t_{o}$ probe. For a sitting position, ISO standard [55] recommends measuring heights for ankle level $0.1 \mathrm{~m}$, abdomen level $0.6 \mathrm{~m}$, and head level $1.1 \mathrm{~m}$. Conformably to Fanger and Christensen [6], mean $v_{a}$ and standard deviation at three heights around the sitting occupant body were measured according to heights shown on Figure 2. RH probe was set at $1.0 \mathrm{~m}$ as a fixed height for measuring has not been fixed for measurements. The $t_{o}$ probe was mounted with the angle of $30^{\circ}$ at the height of $0.6 \mathrm{~m}$ as the abdomen level of a sitting person [55]. 


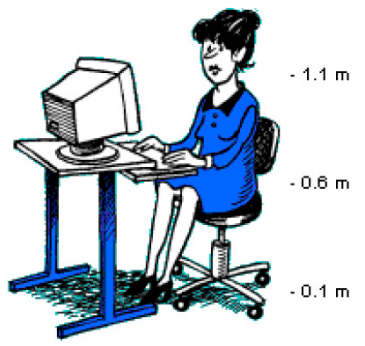

(a)
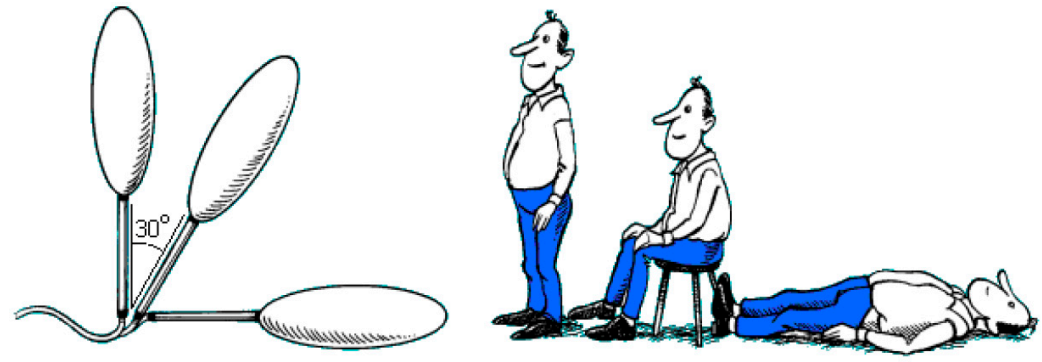

(b)

Figure 2. Recommended air velocity probe heights behind the feet, elbow, and neck for a sitting person (a); Recommended operative temperature probe person's angle factor to their surroundings (b) [58].

Probes were connected with 54N90 ComfortSense main frame [56], using 7 channels of 16 . Main frame was in turn connected with laptop computer where the measurement data was stored using ComfortSense software version 4, (Dantec Dynamics A/S, Skovlunde, Denmark) [56]. Measurement period of 180 seconds as the least time recommended [59] was used.

\subsection{Data Analysis}

Measurement data, including $t_{i}, v_{a}, R H$, and $t_{o}$ was recorded with the sampling rate $20 \mathrm{~Hz}$ with ComfortSense [56] and processed in Microsoft Excel. TC parameters are calculated for each measurement positions with equations for $T u, D R, P M V$, and $P P D$ followed. To assess $D R$, the fluctuation rate of $v_{a}$ is described as $T u$, which is calculated by [59]

$$
T u=\frac{S D}{v_{a}} \times 100(\%),
$$

where $S D$ is standard deviation of measured local mean $v_{a}(\mathrm{~m} / \mathrm{s})$ for one measurement. With $t_{i}, v_{a}$, and $T u$, the percentage of people predicted to be dissatisfied because of draught may be calculated as [60]

$$
D R=\left(34-t_{i}\right) \times\left(v_{a}-0.05\right)^{0.62} \times\left(0.37 \times v_{a} \times T u+3.14\right)(\%)
$$

To predict the mean value of the subjective ratings of a group of people in a given environment, $P M V$ index is used. Consisting of a set of parameters with sub-formulas, the $P M V$ equation is given by [60]

$$
P M V=[0.303 \times \exp (-0.036 \times M)+0.028] \times\left[(M-W)-H_{d}-E_{c}-C_{r e s}-E_{\text {res }}\right]
$$

The $P M V$ index in Equation (3) was calculated using Equations (4)-(11). In the equations provided, $M$ $\left(\mathrm{W} / \mathrm{m}^{2}\right)$ is metabolic rate and $W\left(\mathrm{~W} / \mathrm{m}^{2}\right)$ is the effective mechanical power. Assumption of metabolic rate 1.2 met for sedentary activity for summer season provided in EN 16798-1 was used. Sedentary activity does not suppose producing effective mechanical power, therefore $0\left(\mathrm{~W} / \mathrm{m}^{2}\right)$ was used in analysis. The next symbol $H_{d}$ in Equation (3) represents dry heat loss, which is found as

$$
H_{d}=\frac{\left(m t_{s k}-t_{c l}\right)}{I_{c l}}\left(\mathrm{~W} / \mathrm{m}^{2}\right)
$$

where $m t_{s k}$ is mean skin temperature $\left[{ }^{\circ} \mathrm{C}\right]$ and in Equation (4), $t_{c l}$ is expressed using $t_{\mathrm{o}}$ and calculated through iterative process, by

$$
t_{c l}=35.7-0.028 \times(M-W)-I_{c l} \times\left\{3.96 \times 10^{-8} \times f_{c l} \times\left[\left(t_{c l}+273\right)^{4}-\left(t_{o}+273\right)^{4}\right]+I_{c l} \times f_{c l} \times h_{c} \times\left(t_{c l}-t_{o}\right)\right\}\left({ }^{\circ} \mathrm{C}\right)
$$

In Equation (5), $I_{c l}\left[\left(\mathrm{~m}^{2} \times \mathrm{K}\right) / \mathrm{W}\right]$ is the clothing insulation, $f_{c l}$ is the clothing surface area factor, $v_{a r}(\mathrm{~m} / \mathrm{s})$ is the relative air velocity, $h_{c}\left[\mathrm{~W} /\left(\mathrm{m}^{2} \times \mathrm{K}\right)\right]$ is the convective heat transfer coefficient, and $t_{c l}\left({ }^{\circ} \mathrm{C}\right)$ is the 
clothing surface temperature. Clothing unit 0.5 clo for summer season provided in EN 16798-1 was used in calculations. Equation (5) includes $h_{c}$, which is given as

$$
\begin{gathered}
h_{c}=2.38 \times\left|t_{c l}-t_{i}\right|^{0.25} \text { for } 2.38 \times\left|t_{c l}-t_{i}\right|^{0.25}>12.1 \times \sqrt{v_{a r}} \text { and } \\
12.1 \times \sqrt{v_{a r}} \text { for } 2.38 \times\left|t_{c l}-t_{i}\right|^{0.25}<12.1 \times \sqrt{v_{a r}}\left[\mathrm{~W} /\left(\mathrm{m}^{2} \times \mathrm{K}\right)\right]
\end{gathered}
$$

where $v_{a r}$ was set equal to the $v_{a}$ as occupants were intended to be stationary sensing draught. Equation (5) includes $f_{c l}$, which is calculated by

$$
\begin{aligned}
f_{c l}= & 1.00+1.290 \times I_{c l} \text { for } I_{c l} \leq 0.078 \text { and } \\
& 1.05+0.645 \times I_{c l} \text { for } I_{c l}>0.078
\end{aligned}
$$

Continuing the $P M V$ index calculation, in Equation (3), evaporative heat exchange at the skin, when the person experiences a sensation of thermal neutrality $E_{c}$ given as

$$
E_{c}=3.05 \times 10^{-3} \times\left[5733-6.99 \times(M-W)-p_{a}\right]+0.42 \times(M-W-58.15)\left(\mathrm{W} / \mathrm{m}^{2}\right),
$$

where $p_{a}$ is the water vapor partial pressure [Pa], calculated using measured $R H$ by

$$
p_{a}=\frac{R H}{100} \times 479+\left(11.52+1.62 \times t_{i}\right)^{2}(\mathrm{~Pa}),
$$

In addition, Equation (3) for $P M V$ includes respiratory convective heat exchange $C_{\text {res }}$, calculated as

$$
C_{\text {res }}=0.0014 \times M \times\left(34-t_{i}\right)\left(\mathrm{W} / \mathrm{m}^{2}\right) \text {, }
$$

and Equation (3) includes also respiratory evaporative heat exchange $E_{r e s}$, given as

$$
E_{\text {res }}=1.72 \times 10^{-5} \times M \times\left(5867-p_{a}\right)\left(\mathrm{W} / \mathrm{m}^{2}\right),
$$

Finally, to predict the rate of people dissatisfied in a thermal environment, the PPD index is used. Knowing PMV, PPD can be calculated as [60]

$$
P P D=100-95 \times \exp \left(-0.03353 \times P M V^{4}-0.2179 \times P M V^{2}\right)
$$

Measured values are shown in Building result figures in the results chapter and used in Equations (1) and (2) for calculating $T u$ and $D R$, and in Equations (3) and (12) to calculate PMV and PPD.

\subsection{Indoor Climate Questionnaire}

To study occupant satisfaction we provided online questionnaires to the employees of the measured office spaces. As some organizations involved in this study are moving towards policy of a paperless work management, we used Google Forms [61] application. In addition to standard CEN EN 15251 [52] suggestions, we added also questions about age, gender, amount of time behind the desk during workday, and the working environment regarding cabinet or open office plan. The ICQ is presented in Appendix A.

\subsection{On-Site Measurements}

This section provides an overview of the TC measurement time and weather information (Table 4), followed by measurement results with calculated TC indicative parameters $T u, D R, P M V$, and $P P D$. ICQ survey results are summarized at the end of the results sections. 
Table 4. Time of measurements and weather information from the Estonian Weather Service [62].

\begin{tabular}{|c|c|c|c|c|}
\hline Building & $\begin{array}{c}\text { Time of } \\
\text { Measurements }\end{array}$ & $\begin{array}{l}\text { Weather } \\
\text { Conditions }\end{array}$ & $\begin{array}{c}\text { Maximum } \\
\text { Outdoor Temp. }{ }^{\circ} \mathrm{C}\end{array}$ & $\begin{array}{l}\text { Mean Outdoor } \\
\text { Temp. }{ }^{\circ} \mathrm{C}\end{array}$ \\
\hline A & $\begin{array}{c}06.08 .2019 \\
\text { before midday }\end{array}$ & $\begin{array}{l}\text { cloudy skies } \\
\text { showers }\end{array}$ & +20.9 & +15.2 \\
\hline B & $\begin{array}{c}14.08 .2019 \\
\text { after midday }\end{array}$ & $\begin{array}{c}\text { cloudy skies } \\
\text { no precipitation }\end{array}$ & +19.7 & +13.8 \\
\hline $\mathrm{C}$ & $\begin{array}{c}12.08 .2019 \\
\text { after midday }\end{array}$ & $\begin{array}{l}\text { cloudy skies } \\
\text { light showers }\end{array}$ & +22.0 & +17.3 \\
\hline $\mathrm{D}$ & $\begin{array}{l}29.08 .2019 \\
\text { after midday }\end{array}$ & $\begin{array}{c}\text { sunny skies } \\
\text { no precipitation }\end{array}$ & +26.5 & +20.6 \\
\hline E & $\begin{array}{c}05.08 .2019 \\
\text { after midday }\end{array}$ & $\begin{array}{c}\text { cloudy skies } \\
\text { no precipitation }\end{array}$ & +19.7 & +13.8 \\
\hline
\end{tabular}

The experiments were carried out on regular workdays during August. Measurements were taken by two persons, by the main author of this article assisted by graduate students in different buildings. HVAC systems were in regular performance mode without disfunctions or failures recorded. Internal gains by occupants, office equipment, and lighting were in use by default as some desks were empty by unused space, duties, or vacation. No serious defects in HVAC design or construction were observed. Although, some air flow and velocity aspects were noticeable. As in Buildings A and C, active beams were in use, occupants were not always placed sitting according to rule of thumbs, according to the architectural layout, or number of persons. Possible air flow obstacles by lighting fixture (Figure 3a) were noticed with open ceiling in Building A. DR risk was also predictable in building E (Figure 3b) where some vanes were taped to closed position. $D R$ risk was more carefully considered in Buildings $B$ and D.

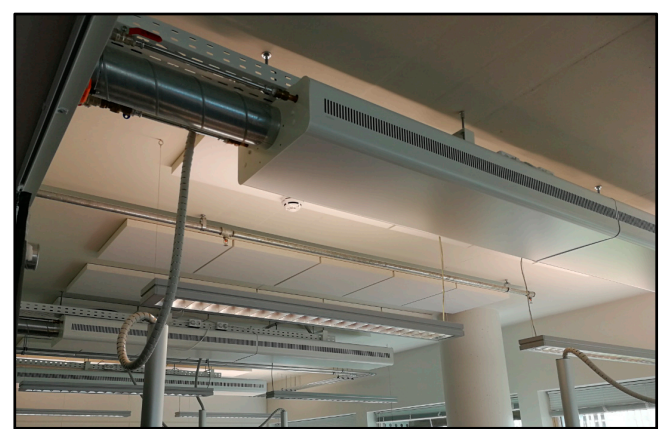

(a)

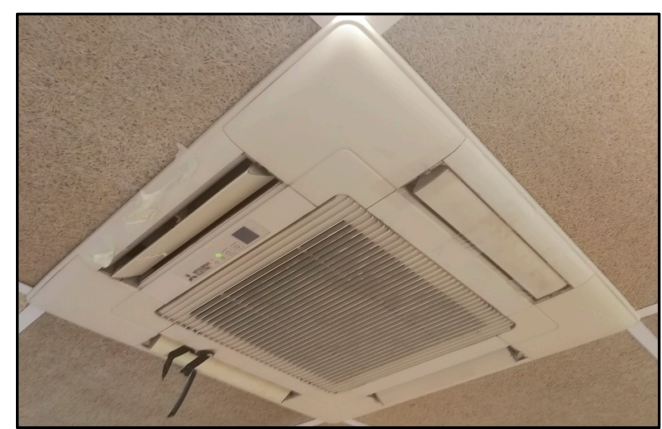

(b)

Figure 3. Possible air flow obstacles with open active beam solution (a); modified airflow distribution with fan coil unit (b).

\section{Results}

Based on on-site measurements, the summary of $v_{a}$ in each measurement position are shown below for each Building. According to three heights provided in Figure 2, $v_{a}$ values during measurement period are shown with box and whiskers plot. Minimum and maximum are at the end of the whiskers, the lower and the upper line of the box are first and third quartiles, the line between is median and the cross shows mean $v_{a}$ value of the measurement in one position.

On the box and whiskers plot, the category of the indoor climate category is colored according to the lowest criteria achieved during measurements, meaning if one of the three height is in III category, the measurement point is placed in the least, III category. In the table part on the result figures below the box and whiskers plot, measured values and calculated parameters are colored according to the 
category reached to be more easily distinguishable. $T u$ and $R H$ measured values are not colored as being not categorized. Nonetheless, measurement point indoor climate category is defined by the inferior measured value or calculated parameter reached altogether.

\subsection{Building A Results}

The $v_{a}$ results and TC parameters in Building A equipped with open ceiling active chilled beams are provided below in Figure 4. In Building A, in 2/3 of the measured positions the $v_{a}$ was below the first indoor climate category threshold. Five positions met the II category requirement and in one position the $v_{a}$ was above the category II threshold. Measurement No 14 was taken in an office space with unusually high internal gains, where also multi-split fan coil units were additionally added to the environment due to the specifics of the lessee. The results of $t_{i}$ and $v_{a}$ including $D R, P M V$, and PPD are placed in the first category mainly.
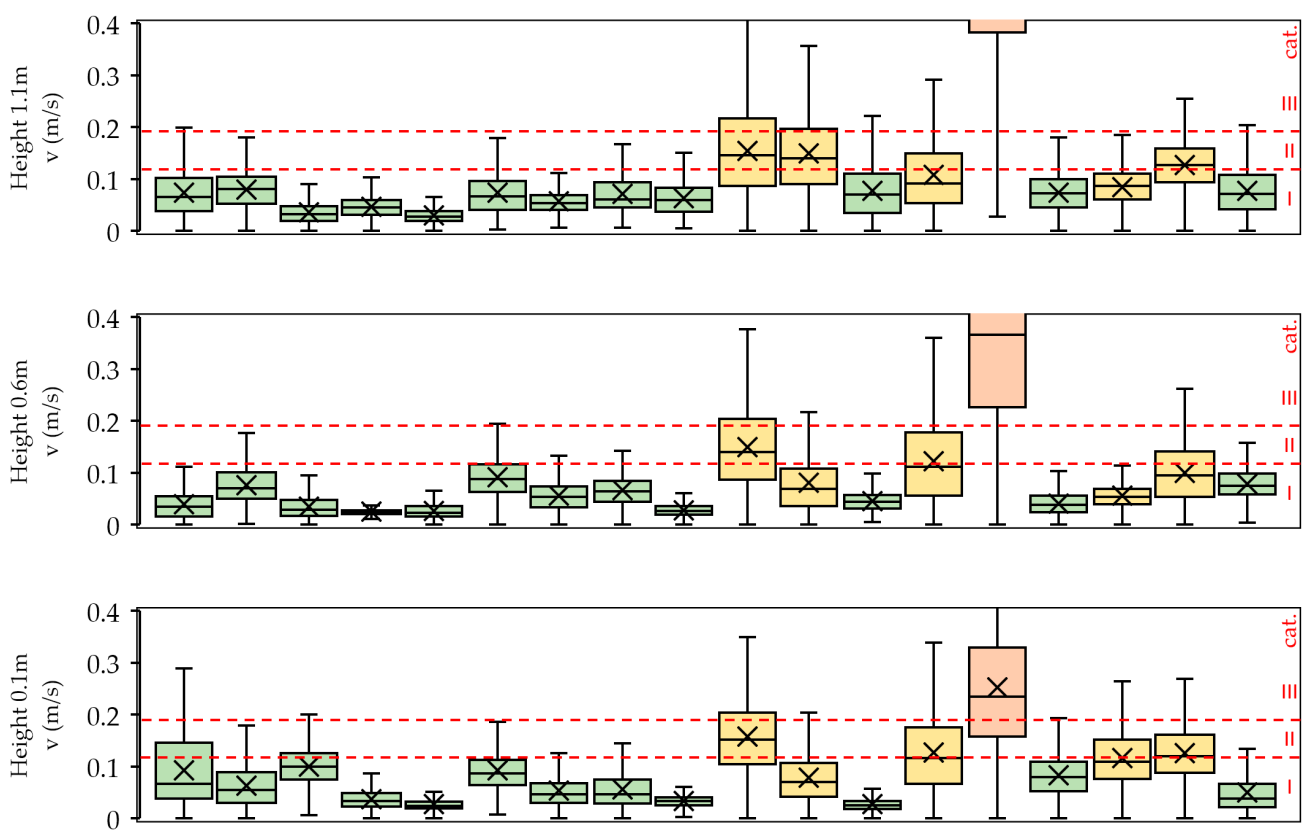

\begin{tabular}{|c|c|c|c|c|c|c|c|c|c|c|c|c|c|c|c|c|c|c|c|}
\hline & & 1 & 2 & 3 & 4 & 5 & 6 & 7 & 8 & 9 & 10 & 11 & 12 & 13 & 14 & 15 & 16 & 17 & 18 \\
\hline $1.1 \mathrm{~m}$ ) & ${ }^{\circ} \mathrm{C}$ & 24.5 & 23.7 & 23.8 & 24.1 & 24.5 & 24.6 & 24.1 & 24.0 & 24.5 & 24.4 & 23.6 & 24.2 & 23.5 & 2.1 & 24.2 & 23.9 & 23.8 & 24.5 \\
\hline$v a(1.1$, & $\mathrm{m} / \mathrm{s}$ & 0.07 & 0.08 & 0.04 & 0.05 & 0.03 & 0.07 & 0.06 & 0.07 & 0.06 & 0.15 & 0.15 & 0.08 & 0.11 & 0.61 & 0.07 & 0.08 & 0.13 & 0.08 \\
\hline$T u(1.1$ & $\%$ & 65.3 & 47.9 & 58.0 & 46.9 & 49.5 & 59.4 & 44.3 & 55.0 & 51.4 & 58.7 & 55.0 & 68.3 & 66.6 & 48.2 & 47.9 & 45.9 & 39.1 & 58.9 \\
\hline$D R(1.1$ & $\%$ & 4.7 & 5.2 & 0 & 0. & 0.0 & 4.3 & 1.9 & 4.2 & 2.7 & 15.3 & 15.4 & 5.3 & 10.5 & 100.0 & 4.3 & 5.7 & 10.3 & 4.9 \\
\hline$t_{i}(0.6 \mathrm{~m})$ & ${ }^{\circ} \mathrm{C}$ & 24.2 & 23.5 & 23.6 & 23.9 & 24.2 & 24.3 & 23.9 & 23.8 & 23.8 & 24.2 & 23.5 & 23.9 & 23.3 & 22.2 & 24.1 & 23.8 & 23.7 & 24.4 \\
\hline$t_{o}(0.6 \mathrm{~m})$ & ${ }^{\circ} \mathrm{C}$ & 24.7 & 23.7 & 23.8 & 24.3 & 24.6 & 24.7 & 24.2 & 24.1 & 24.6 & 24.7 & 23.9 & 24.1 & 23.6 & 22.9 & 24.2 & 24.2 & 24.1 & 24.7 \\
\hline$v a(0.6 \mathrm{~m})$ & $\mathrm{m} / \mathrm{s}$ & 0.04 & 0.08 & 0.03 & 0.02 & 0.03 & 0.09 & 0.06 & 0.07 & 0.03 & 0.15 & 0.08 & 0.05 & 0.12 & 0.43 & 0.04 & 0.06 & 0.10 & 0.08 \\
\hline$R H_{(0.6}$ & $\%$ & 50.5 & 52. & 54.4 & 52.6 & 51. & 52.1 & 51.7 & 52.1 & 50.9 & 52.1 & 55.9 & 53.4 & 49 & 52.7 & 52.5 & 53.2 & 55.3 & 54.0 \\
\hline$P M V(0.6 \mathrm{~m})$ & - & 0.0 & -0.3 & -0.2 & -0.1 & 0.0 & 0.0 & -0.1 & -0.2 & 0.0 & -0.2 & -0.2 & -0.1 & -0.4 & -1.3 & -0.1 & -0.1 & -0.2 & 0.0 \\
\hline$P P D(0.6 \mathrm{~m})$ & \% & 5.0 & 6.4 & 6 & 5.2 & 5.0 & 5.0 & 5.2 & 5.5 & 5.0 & 5.5 & 5.7 & 5.3 & 8.6 & 39.2 & 5.3 & 5.2 & 5.5 & 5.0 \\
\hline
\end{tabular}

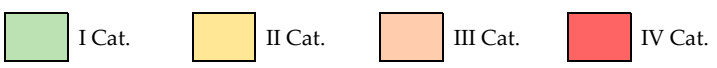

Figure 4. Building A air velocity results in measurement points 1-18 and the thermal comfort parameters. 


\subsection{Building $B$ Results}

The $v_{a}$ results and TC parameters of Building B with slab-based TABS system are given below in Figure 5. Building B had more measured points in the second category by $P M V$ and $P P D$ compared to Building A. DR met the II category in four measurement positions. Positions $4-8$ were in an office, where the ventilation rate had been doubled by the request of the lessee. These four measurements stand out above the others. Regarding the other four buildings observed, displacement ventilation effect can be seen, as $v_{a}$ fluctuates more near the floor.
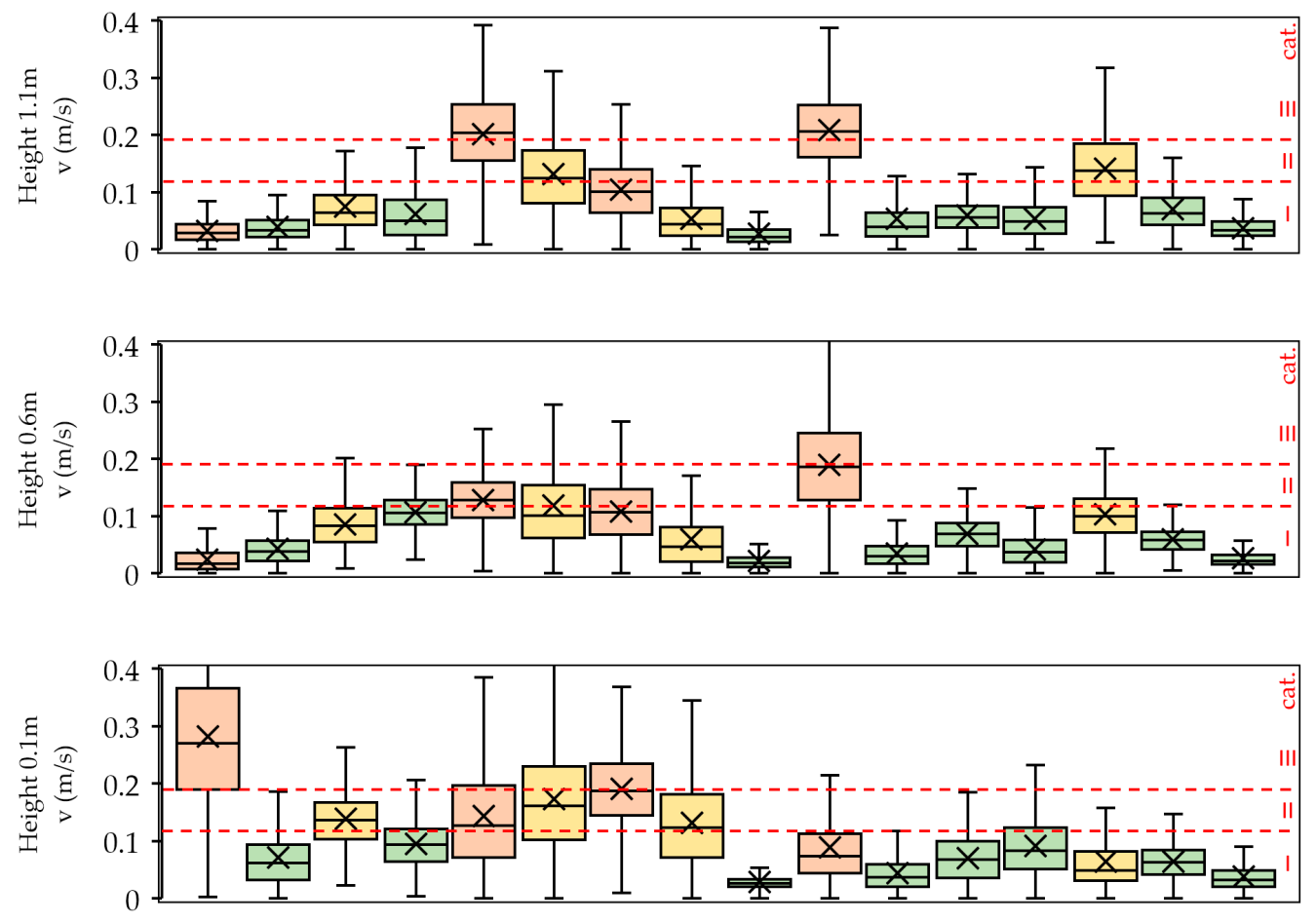

\begin{tabular}{|c|c|c|c|c|c|c|c|c|c|c|c|c|c|c|c|c|c|}
\hline & & 1 & 2 & 3 & 4 & 5 & 6 & 7 & 8 & 9 & 10 & 11 & 12 & 13 & 14 & 15 & 16 \\
\hline$t i(1.1 \mathrm{~m})$ & ${ }^{\circ} \mathrm{C}$ & 23.5 & 23.7 & 23.8 & 23.5 & 24.3 & 23.8 & 23.9 & 24.3 & 23.6 & 23.6 & 24.2 & 23.4 & 23.8 & 24.7 & 24.0 & 24.6 \\
\hline$v a(1.1 \mathrm{~m})$ & $\mathrm{m} / \mathrm{s}$ & 0.03 & 0.04 & 0.08 & 0.06 & 0.20 & 0.13 & 0.10 & 0.05 & 0.03 & 0.21 & 0.05 & 0.06 & 0.05 & 0.14 & 0.07 & 0.04 \\
\hline $\mathrm{Tu}(1.1 \mathrm{~m})$ & $\%$ & 64.2 & 82.9 & 63.4 & 77.4 & 36.4 & 53.3 & 50.7 & 79.9 & 84.2 & 32.6 & 102.3 & 48.1 & 62.2 & 43.9 & 58.9 & 49.7 \\
\hline$D R(1.1 \mathrm{~m})$ & $\%$ & 0.0 & 0.0 & 5.1 & 3.2 & 17.7 & 12.3 & 8.5 & 1.3 & 0.0 & 18.7 & 1.6 & 2.5 & 1.3 & 11.5 & 4.2 & 0.0 \\
\hline$t i(0.6 \mathrm{~m})$ & ${ }^{\circ} \mathrm{C}$ & 23.4 & 23.5 & 23.6 & 23.5 & 24.1 & 23.7 & 23.7 & 24.1 & 24.1 & 23.5 & 24.0 & 23.1 & 23.4 & 24.5 & 23.8 & 24.4 \\
\hline$t_{o(0.6 \mathrm{~m})}$ & ${ }^{\circ} \mathrm{C}$ & 23.4 & 23.9 & 24.1 & 23.5 & 24.4 & 23.8 & 24.0 & 24.3 & 23.6 & 23.7 & 24.5 & 23.3 & 23.8 & 24.7 & 24.3 & 24.3 \\
\hline$v a(0.6 \mathrm{~m})$ & $\mathrm{m} / \mathrm{s}$ & 0.02 & 0.04 & 0.09 & 0.11 & 0.13 & 0.12 & 0.11 & 0.06 & 0.02 & 0.19 & 0.03 & 0.07 & 0.04 & 0.10 & 0.06 & 0.03 \\
\hline$R H(0.6 \mathrm{~m})$ & $\%$ & 49.5 & 50.5 & 49.3 & 50.9 & 46.5 & 45.9 & 45.7 & 45.9 & 46.8 & 47.8 & 47.4 & 48.5 & 46.9 & 47.5 & 49.0 & 47.6 \\
\hline$P M V(0.6 \mathrm{~m})$ & - & -0.4 & -0.2 & -0.2 & -0.4 & -0.2 & -0.4 & -0.3 & -0.1 & -0.3 & -0.6 & -0.1 & -0.4 & -0.3 & 0.0 & -0.1 & -0.1 \\
\hline$P P D(0.6 \mathrm{~m})$ & $\%$ & 8.1 & 6.2 & 5.6 & 8.1 & 6.1 & 7.9 & 6.6 & 5.4 & 7.1 & 12.2 & 5.1 & 8.8 & 6.8 & 5.0 & 5.3 & 5.3 \\
\hline
\end{tabular}

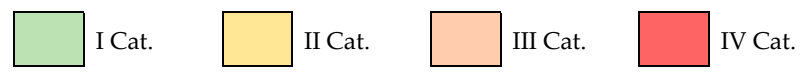

Figure 5. Building B air velocity results in measurement points 1-16 and the thermal comfort parameters.

\subsection{Building C Results}

Building $C$ was equipped with suspended ceiling active chilled beams and the results of $v_{a}$ and parameters of TC are presented below in Figure 6. PMV, PPD, and $t_{i}$ were similar to Buildings $\mathrm{A}$ and 
$\mathrm{B}$, at the same time $v_{a}$ and $D R$ were measured at two positions in the II category and three times in the III category. The $v_{a}$ is more fluctuating on the height of the sitting person neck.
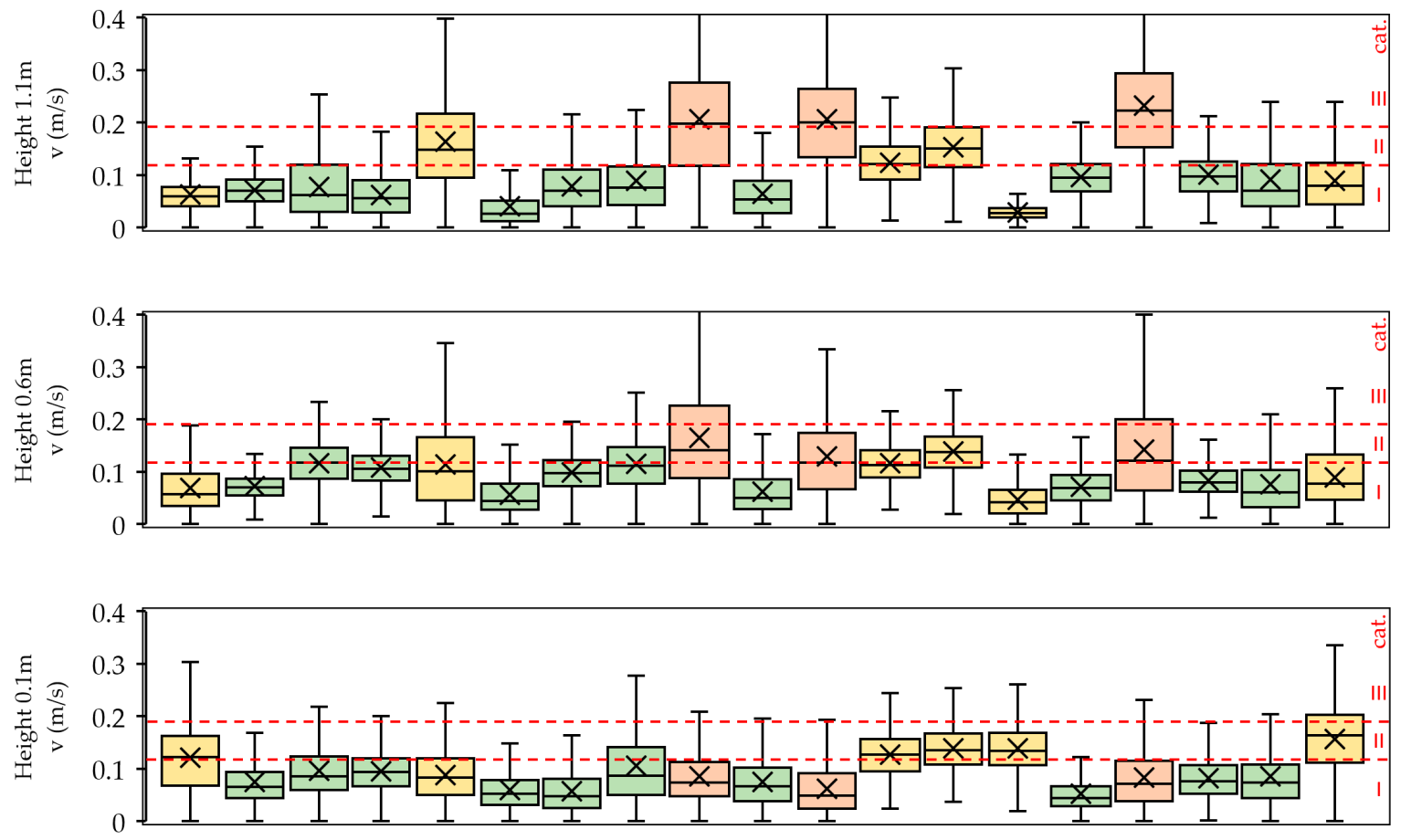

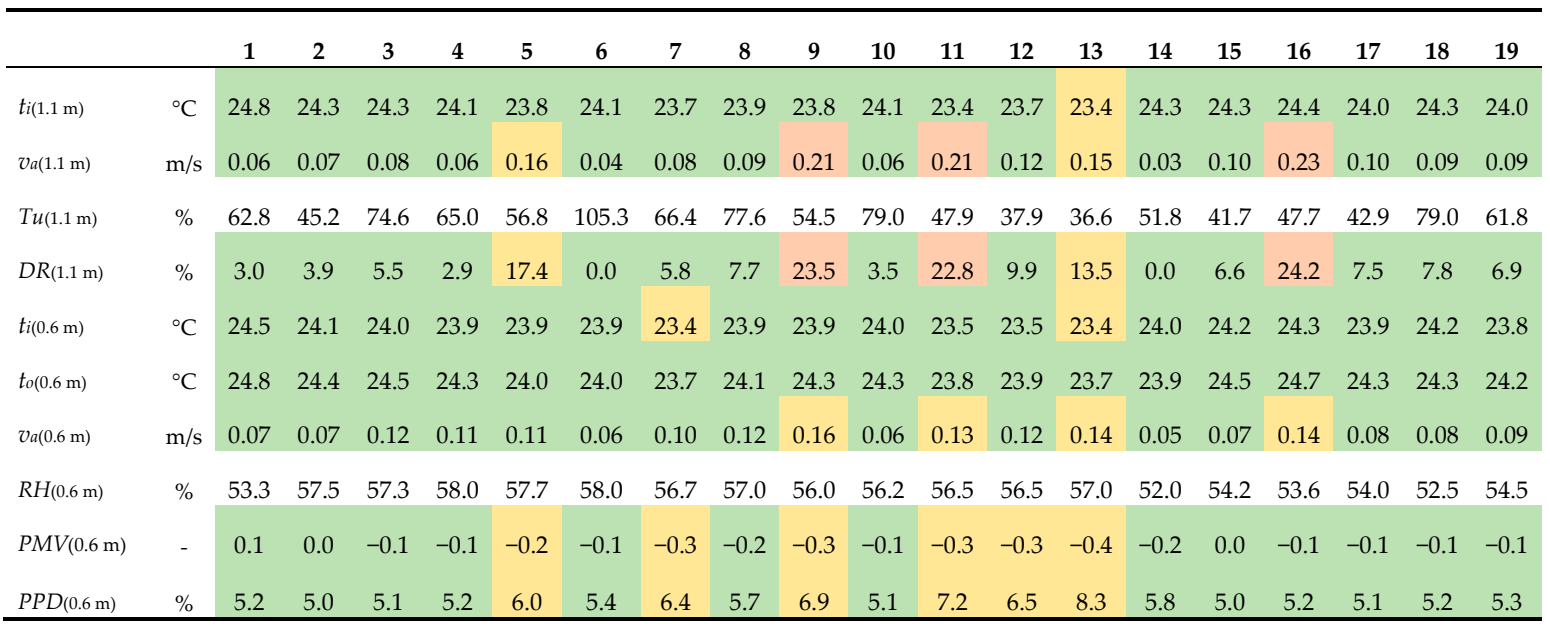

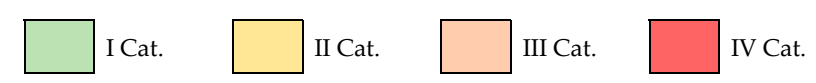

Figure 6. Building $C$ air velocity results in measurement points 1-19 and the thermal comfort parameters.

\subsection{Building D Results}

Equipped with radiant cooling panels, results of $v_{a}$ and parameters of TC in Building D are showed below in Figure 7. Compared to other buildings, Building $D$ with the least number of positions had the best results on all analyzed parameters. In all cases, I category $D R$ was achieved. At all times, mean $v_{a}$ remained below $0.10 \mathrm{~m} / \mathrm{s}$ being more fluctuating near the floor. 

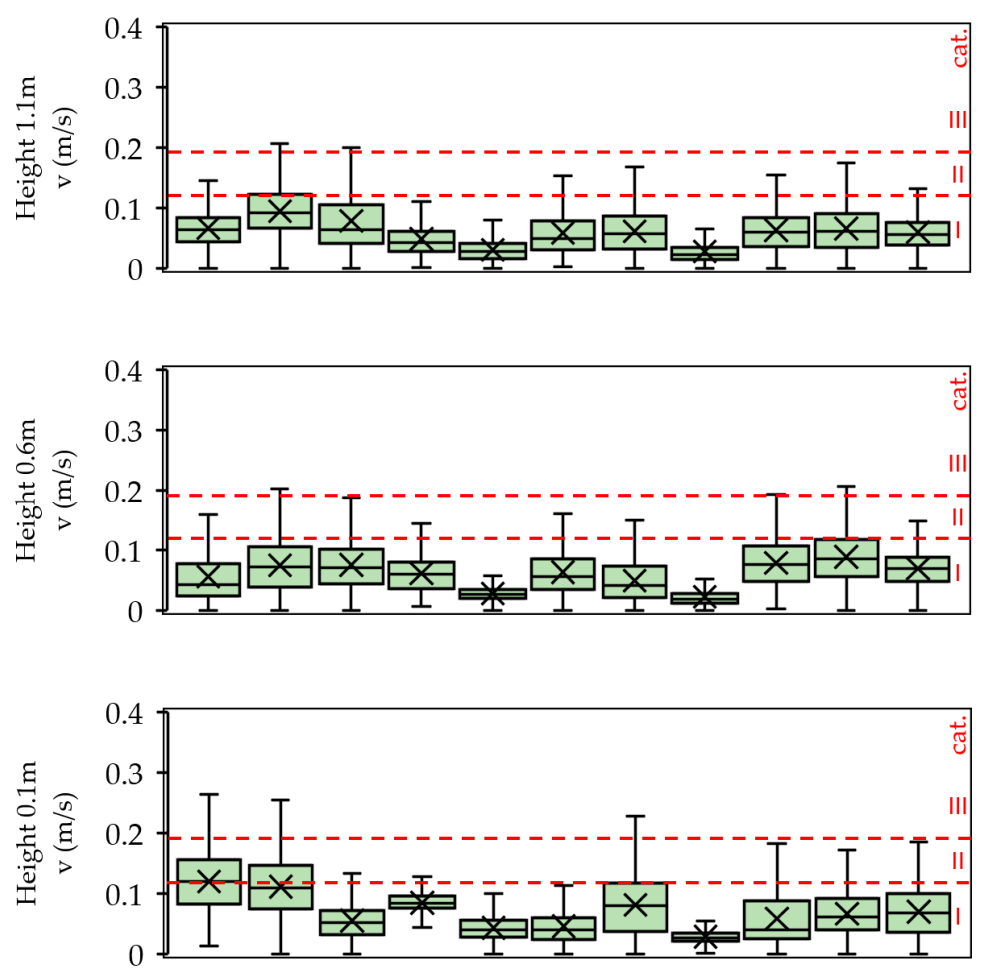

\begin{tabular}{|c|c|c|c|c|c|c|c|c|c|c|c|c|}
\hline & & 1 & 2 & 3 & 4 & 5 & 6 & 7 & 8 & 9 & 10 & 11 \\
\hline$t i(1.1 \mathrm{~m})$ & ${ }^{\circ} \mathrm{C}$ & 24.8 & 24.2 & 24.2 & 24.2 & 24.2 & 24.2 & 23.3 & 23.6 & 24.5 & 23.9 & 23.4 \\
\hline$v a(1.1 \mathrm{~m})$ & $\mathrm{m} / \mathrm{s}$ & 0.07 & 0.09 & 0.08 & 0.05 & 0.03 & 0.06 & 0.06 & 0.03 & 0.06 & 0.07 & 0.06 \\
\hline$T u(1.1 \mathrm{~m})$ & $\%$ & 53.5 & 47.5 & 66.6 & 72.1 & 66.1 & 73.6 & 62.7 & 84.2 & 58.8 & 59.9 & 48.1 \\
\hline$D R(1.1 \mathrm{~m})$ & $\%$ & 3.2 & 6.8 & 5.5 & 0.0 & 0.0 & 2.4 & 2.9 & 0.0 & 2.9 & 3.6 & 2.5 \\
\hline$t i(0.6 \mathrm{~m})$ & ${ }^{\circ} \mathrm{C}$ & 24.4 & 24.0 & 24.1 & 24.0 & 24.1 & 24.1 & 23.4 & 23.4 & 23.4 & 23.5 & 23.1 \\
\hline$t_{o(0.6 \mathrm{~m})}$ & ${ }^{\circ} \mathrm{C}$ & 24.3 & 23.8 & 24.0 & 24.0 & 24.0 & 24.0 & 23.1 & 23.6 & 24.8 & 23.7 & 23.3 \\
\hline$v_{a(0.6 \mathrm{~m})}$ & $\mathrm{m} / \mathrm{s}$ & 0.06 & 0.07 & 0.07 & 0.06 & 0.03 & 0.06 & 0.05 & 0.02 & 0.08 & 0.09 & 0.07 \\
\hline$R H(0.6 \mathrm{~m})$ & $\%$ & 58.0 & 57.8 & 57.2 & 57.4 & 57.8 & 58.0 & 59.9 & 46.8 & 57.2 & 59.7 & 48.5 \\
\hline$P M V(0.6 \mathrm{~m})$ & - & 0.0 & -0.2 & -0.1 & -0.1 & -0.1 & -0.1 & -0.4 & -0.3 & 0.1 & -0.2 & -0.4 \\
\hline$P P D(0.6 \mathrm{~m})$ & $\%$ & 5.1 & 5.7 & 5.4 & 5.4 & 5.4 & 5.3 & 8.5 & 7.3 & 5.1 & 6.1 & 8.8 \\
\hline
\end{tabular}

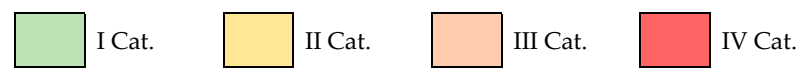

Figure 7. Building D air velocity results in measurement points 1-11 and the thermal comfort parameters.

\subsection{Building E Results}

According to the results, Building E achieved the worst TC values by categories. DR was in the II category in 4 positions of $14, t_{i}$ was in III category four times. PMV and PPD second category was not reached 5 times. Fluctuations of $v_{a}$ were random depending on the height. The $v_{a}$ results and TC parameters in Building E, with fan coil units mounted in the suspended ceiling, are compared below in Figure 8. 

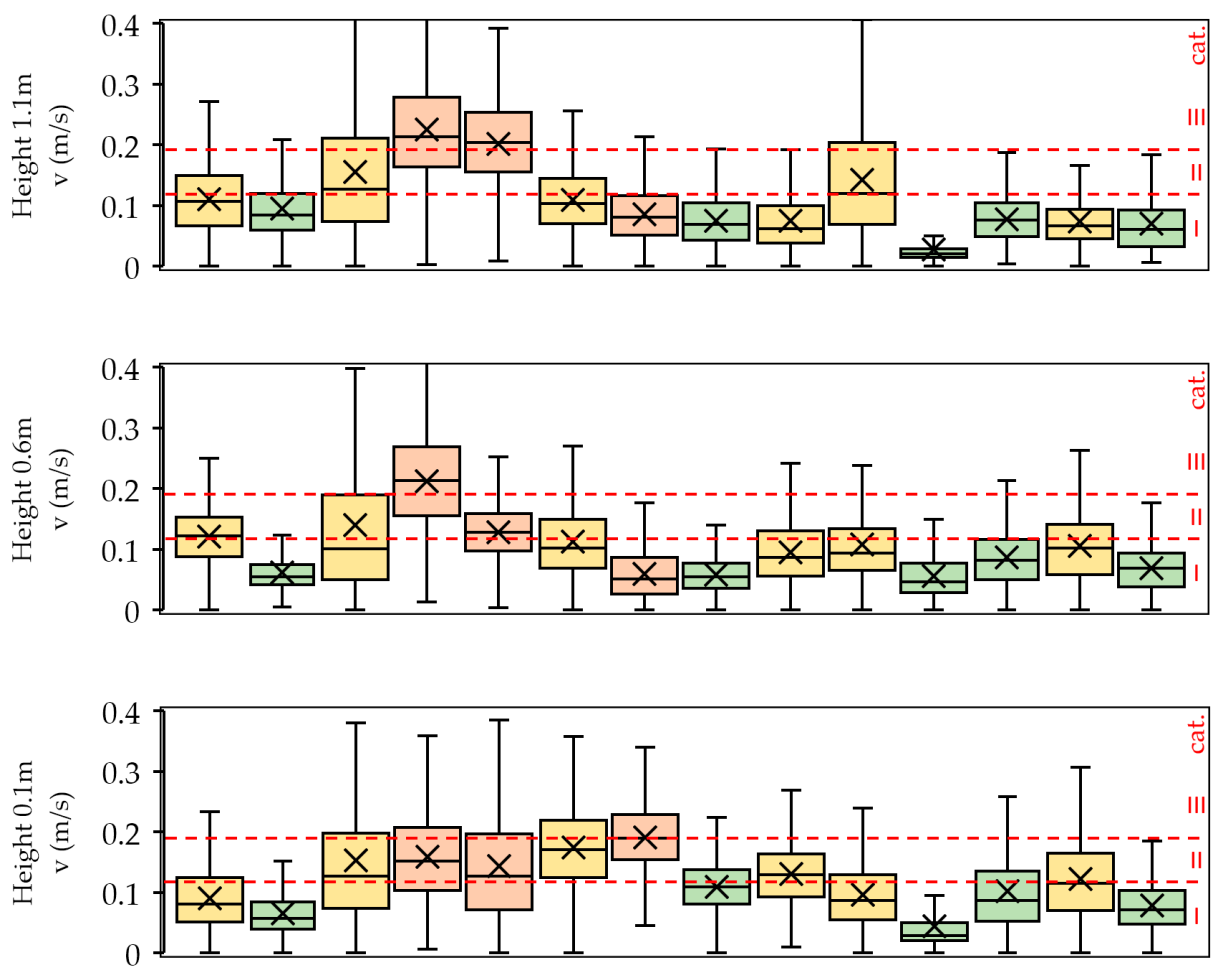

\begin{tabular}{|c|c|c|c|c|c|c|c|c|c|c|c|c|c|c|c|}
\hline & & 1 & 2 & 3 & 4 & 5 & 6 & 7 & 8 & 9 & 10 & 11 & 12 & 13 & 14 \\
\hline$t_{i(1.1 \mathrm{~m})}$ & ${ }^{\circ} \mathrm{C}$ & 25.8 & 25.9 & 25.4 & 25.4 & 24.3 & 25.3 & 25.5 & 25.8 & 25.9 & 25.7 & 26.1 & 26.5 & 26.6 & 27.0 \\
\hline$v a(1.1 \mathrm{~m})$ & $\mathrm{m} / \mathrm{s}$ & 0.11 & 0.10 & 0.15 & 0.23 & 0.20 & 0.11 & 0.09 & 0.08 & 0.07 & 0.14 & 0.03 & 0.08 & 0.07 & 0.07 \\
\hline$T u(1.1 \mathrm{~m})$ & $\%$ & 51.7 & 55.6 & 73.4 & 41.4 & 36.4 & 49.6 & 55.1 & 56.0 & 66.6 & 67.3 & 84.1 & 50.0 & 55.4 & 68.1 \\
\hline$D R(1.1 \mathrm{~m})$ & $\%$ & 7.6 & 6.1 & 15.7 & 19.3 & 17.7 & 7.7 & 5.3 & 4.0 & 4.0 & 12.8 & 0.0 & 3.7 & 3.4 & 3.0 \\
\hline$t i(0.6 \mathrm{~m})$ & ${ }^{\circ} \mathrm{C}$ & 25.7 & 25.8 & 25.0 & 25.1 & 24.1 & 25.2 & 25.3 & 25.6 & 25.6 & 25.5 & 25.7 & 26.1 & 26.2 & 26.4 \\
\hline$t_{o(0.6 \mathrm{~m})}$ & ${ }^{\circ} \mathrm{C}$ & 25.8 & 25.8 & 25.5 & 25.6 & 24.4 & 25.6 & 26.2 & 26.7 & 27.0 & 25.9 & 26.3 & 27.4 & 27.1 & 27.8 \\
\hline$v a(0.6 \mathrm{~m})$ & $\mathrm{m} / \mathrm{s}$ & 0.12 & 0.06 & 0.14 & 0.21 & 0.13 & 0.11 & 0.06 & 0.06 & 0.10 & 0.11 & 0.06 & 0.09 & 0.11 & 0.07 \\
\hline$R H(0.6 \mathrm{~m})$ & $\%$ & 38.4 & 37.5 & 38.8 & 38.6 & 46.5 & 38.2 & 37.9 & 37.5 & 37.4 & 38.2 & 36.6 & 36.2 & 36.6 & 35.9 \\
\hline$P M V(0.6 \mathrm{~m})$ & - & 0.2 & 0.3 & 0.0 & -0.1 & -0.2 & 0.1 & 0.4 & 0.5 & 0.6 & 0.2 & 0.4 & 0.7 & 0.6 & 0.8 \\
\hline$P P D(0.6 \mathrm{~m})$ & $\%$ & 5.7 & 6.7 & 5.0 & 5.2 & 6.1 & 5.4 & 8.0 & 10.9 & 11.5 & 6.2 & 8.4 & 14.8 & 11.8 & 19.9 \\
\hline
\end{tabular}

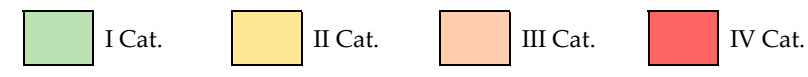

Figure 8. Building E air velocity results in measurement points 1-14 and the thermal comfort parameters.

\subsection{Results of the Indoor Climate Questionnaire}

Based on ICQ survey, summary of the results for thermal environment are shown below in Figure 9, the ICQ results for $P M V$ and $P P D$ are presented below in Figure 10. The highest number of answers were in the Building A with 36 responses divided between all age groups equally between men and women. A total of $83 \%$ were working in open office layout and $86 \%$ were spending most of the day at their workplace. For $83 \%$ of the respondents, $t_{i}$ was described as suitable. Meanwhile, 6 occupants found it to be warm and 7 slightly cooler. A total of $89 \%$ had not or had perceived slight odor, $72 \%$ did not find lighting fixtures or sunlight to be disturbing, and $81 \%$ found ICQ to be suitable or better. A total of $61 \%$ perceived overall acoustics and $36 \%$ perceived other noises to be disturbing. Roughly half of the respondents rarely felt eye problems, headaches, or concentration matters and 
$64 \%$ rarely felt nasal or throat irritation. Extra comments mentioned occasional lack of ventilation and air dryness.
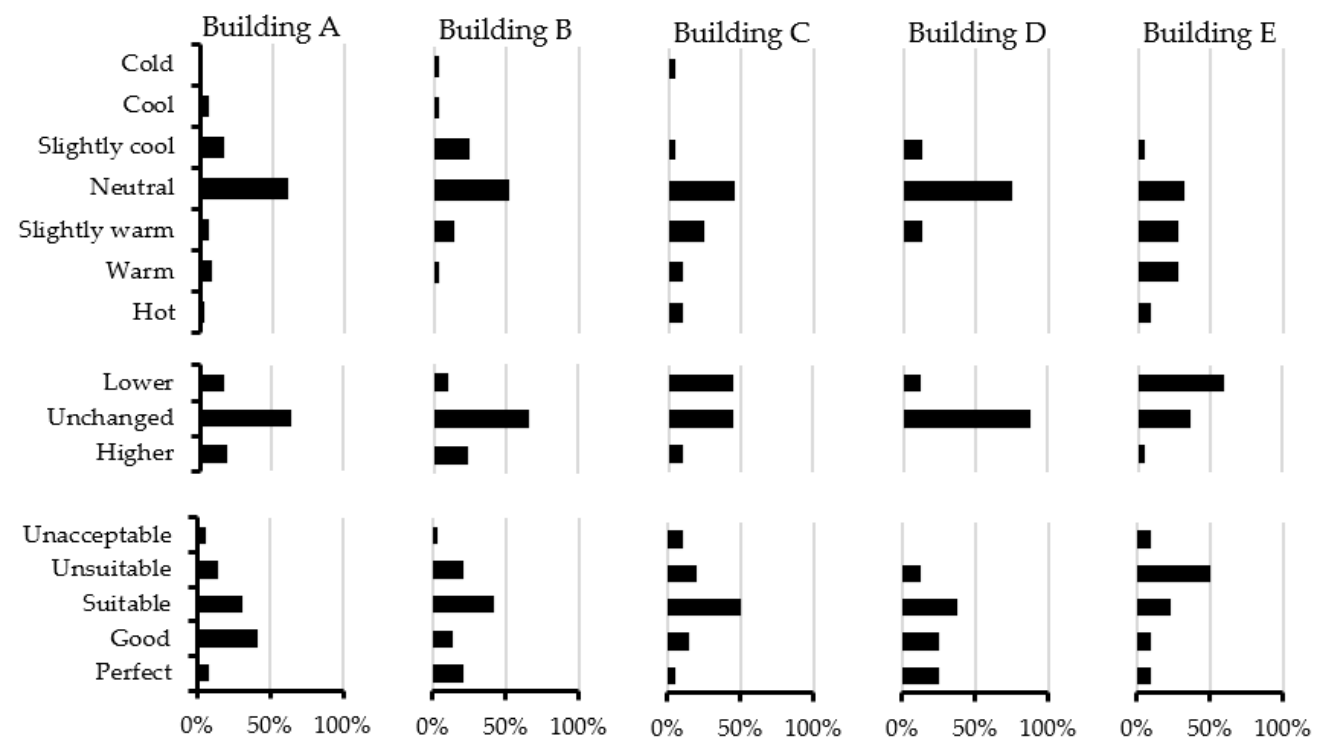

Figure 9. Indoor climate questionnaire results for indoor air temperature. The descriptions of y-axis are the room air temperature sensation question (upper) and verification questions (middle and lower) from the indoor climate questionnaire (see Appendix A).

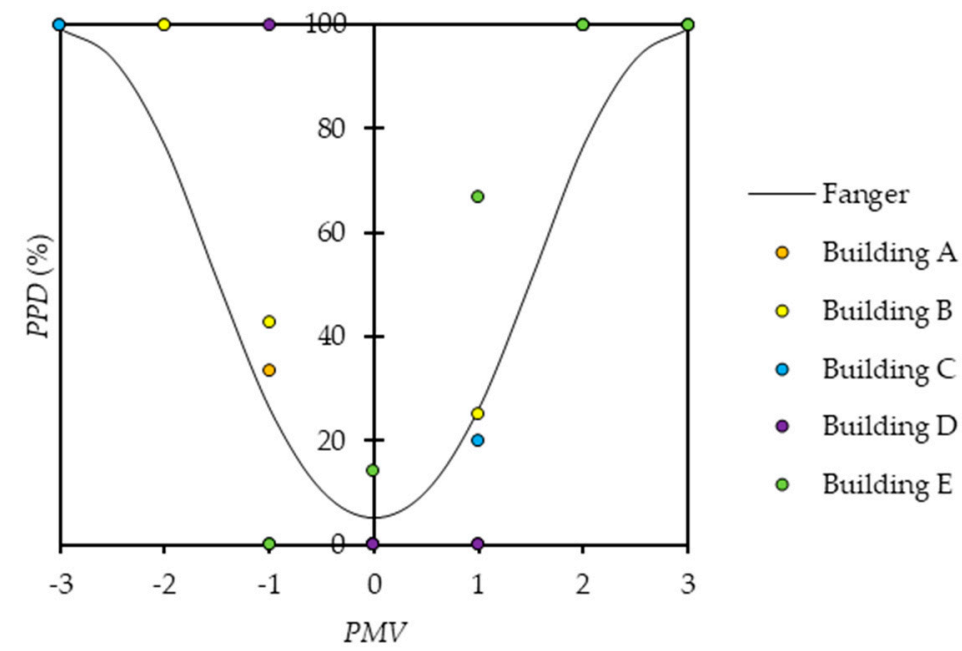

Figure 10. Indoor climate questionnaire results for predicted percentage of dissatisfied and predicted mean vote.

Respondents in the Building B were 38\% females, 2/3 aged between $26-35$ or $36-45$ and 1/2 spending half of the workday behind the desk. A total of $72 \%$ of them working in open office environment. Ninety percent found $t_{i}$ to be suitable. A total of 13 of the 29 respondents did not perceive odor. Lighting was disturbing for $21 \%$ and sunlight for $14 \%$, meanwhile $14 \%$ were dissatisfied with ICQ. Seven percent did not find room acoustics and $17 \%$ general noise in office to be disturbing. Half of the respondents had rarely felt eye dryness or irritation, occur headaches or fatigue, and felt nasal problem or dry throat. A total of $62 \%$ had rarely felt concentration problems.

Seventy percent of the 20 ICQ respondents in Building C were women. Answers were divided between the age of 26 to 65 with the majority of them working in open office landscape, 2/3 working behind their desk most of the day. Perceived as too warm by $20 \%, t_{i}$ was suitable by $75 \%$ of the 
occupants. Ninety percent had not perceived or had perceived slight odor. A total of $70 \%$ did not find lighting equipment to be disturbing and $75 \%$ was not disturbed by the sunlight. Forty percent of the respondents found air quality to be not suitable or unacceptable. A total of $85 \%$ perceived colleagues' speech and overall room acoustic to be somewhat disturbing, while $65 \%$ claimed other noises to be distracting. A total of $1 / 3$ had rarely felt eye problems, occurred headaches, or tiredness. A total of $45 \%$ had rarely felt nasal or throat irritation and $20 \%$ had rarely had concentration issues. Extra comments mentioned lower fresh air rate in the end of the day.

Building D had only 8 responses for the online ICQ all of them working in the open office. For the majority of the answers, $t_{i}$ was suitable. Odor was rarely noticed, lighting or sunlight was not disturbing. ICQ was suitable or better, while room acoustics was more disturbing than other noises. Nasal issues were more often to occur compared to eye dryness or headaches and concentration issues. Extra comments noted that open office may be cheaper option for the employer being unsuitable for the employees.

A total of $2 / 3$ of the 22 respondents in Building $E$ were in the second age group between 26-35 years and $36 \%$ in overall were females. A total of $77 \%$ of the tenants were working in an open office environment, while $2 / 3$ of them were spending most of their day behind the desk. One-third found $t_{i}$ to be suitable and $2 / 3$ claimed the $t_{i}$ to be slightly warm, warm, or hot. Fifty percent perceived weak or moderate odor. Room lighting equipment did not disturb $82 \%$ and the sun did not disturb $60 \%$ of the respondents. A total of $2 / 3$ marked ICQ suitable, good, or very good. Room acoustic level was not claimed to be disturbing for $40 \%$ and other noise for $23 \%$ of the respondents. Fifty percent had rarely felt eye dryness or irritation, $64 \%$ had rarely occur headaches or fatigue, $82 \%$ had rarely felt nasal problems or dry throat, and 50\% mentioned concentration issues sometimes, often, or all the time. Extra comments noted that air quality decreases in the second phase of the day and the missing option for opening windows was also described as a disadvantage.

Number of respondents of the ICQ is below the least recommended sample size [63], therefore the results of the ICQ include higher uncertainty (Figure 10). Thermal sensation voted by occupants covers significantly wider range than $P M V$ calculated from measurements. Majority of the respondents were working in open office. The most unsatisfying $t_{i}$ was in the Building $\mathrm{E}$ and the most suitable $t_{i}$ was in the Building D. In general, unsuitable $t_{i}$ was perceived more as warmer than cooler. In Buildings A, B, and D the $t_{i}$ was perceived suitable for over $80 \%$ of the employees, while it was $67 \%$ in the Building $\mathrm{E}$ and the $60 \%$ in the Building C.

\section{Discussion}

The on-site measurement results showed, that the during cooling summertime $D R$ risk can be stated in all observed buildings. Preconception of avoiding fan coil units for cooling does not immediately guarantee a superior thermal environment without draught. However, draught risk was the lowest in Building D with radiant cooling panels as room conditioning units.

Possible causes, $v_{a}$ and $D R$ was not significantly higher in the case of fan coil units in Building $\mathrm{E}$ was the taping of air distribution vanes (Figure $3 \mathrm{~b}$ ) and also positioning of the working stations was carried out avoiding direct draught from the fan coil units. This could explain the higher thermal environment temperatures. The induced airflow rate is manually adjustable for open ceiling active chilled beams in Building A and was adjusted into different positions for avoiding possible draught between two beams in various places. In Building C, few suspended ceiling active chilled beams had paper covers blocking air flow from the nozzles. These modifications were made due to the complaints, decrease in productivity or spatial plan and the layout of the workspaces. Described modifications in Buildings A, C, and E refer to possible ineffective floor space areas. Therefore, whether the design or construction may have been inaccurate or user-based thermal environment setpoints do not meet the requirements for $v_{a}$ and $D R$.

The $v_{a}$ limit values in EN 16798-1:2019 [54] have been calculated assuming $t_{0}+23^{\circ} \mathrm{C}$ and $\mathrm{Tu} 40 \%$. Figure 11a illustrates that the $T u$ is considerably higher than the default value, which increases the 
unsatisfaction with local TC. However, the measured $t_{0}$ was higher than the default value in most of the measured positions in all buildings, which decreases the number of dissatisfied. Figure 11b shows that, in general, the $D R$ calculated based on measured $t_{o}$ and $T u$ is in the same scale with the one calculated with the default values.

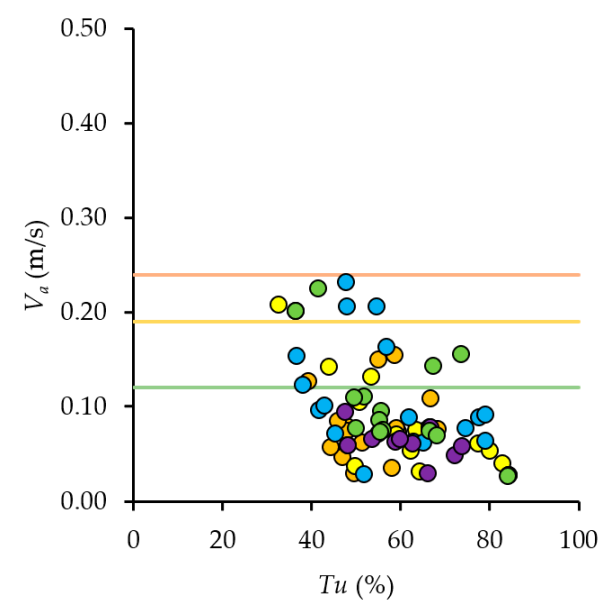

(a)

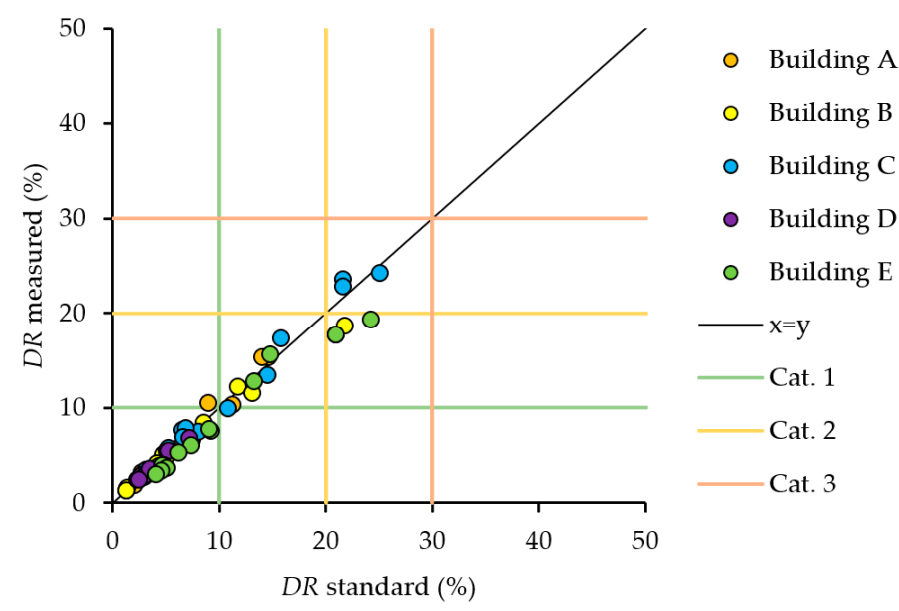

(b)

Figure 11. Air velocity and turbulence intensity results according to maximum air velocity categories I-III in summer (a); Draught rate correlation in measured and standard-based [54] conditions according to draught rate categories I-III (b).

In further analysis of this study $t_{i}$ will be more deeply discussed, foreseeing to include transitional period and heating period measurements, façade inspection and $t_{i}$ periodical data analysis in the reference buildings. Therefore, the performance of the cooling units according to $t_{i}$ could be more clearly presented by period or duration curve. Periodical data analysis on $t_{i}$ is mandatory as $t_{i}$ presented in this study reflects only a fragment of the thermal environment. Positioning TC measurement values on periodical $t_{i}$ data can indicate TC measurement accuracy and dispersion. IQC survey number of respondents also needs additional attention, how to achieve a higher response rate.

There are several limitations to this work. Authors had no control over the boundary conditions during measurements. This study only focuses on a few office spaces in five different building in Tallinn. More further studies of actual work environment need to be performed in order to be able to draw general conclusions about studied room conditioning solutions air distribution performance.

\section{Conclusions}

This study was based on TC measurements in open office environments in Tallinn. First or second category measured general thermal comfort in four buildings out of five were still inconvenient for significant number of occupants because of local thermal discomfort caused by draught and by some additional dissatisfaction indicated by questionnaires. Questionnaire survey showed deviation from predicted PPD in both directions. Some small occupant groups were either more satisfied or less satisfied at slightly cool or slightly warm thermal sensation, but at neutral sensation the results were more consistent. Less satisfied occupant groups exposed to higher air velocities has likely affected their satisfaction reported in thermal sensation questions because there was no specific draught question available.

Temperature measurements showed that air and operative temperature was the worst in Building E which was close to drop out from category III, while measurement results in Buildings A-D remained in between I and II category. According to the questionnaire over $80 \%$ of the employees in Buildings A, B, and C, and 75\% in Building D were thermally satisfied. In the Building E, 59\% of occupants found the thermal environment unsuitable or unacceptable. Generally, the average thermal satisfaction of occupants was well in line with the measurements. 
Air velocity and draught rate measurements showed that modern offices do not necessarily reach to generally expected good indoor climate category II air velocity and draught rate values. A room conditioning solution with suspended ceiling active chilled beams in Building C, displacement ventilation in Building B with TABS and fan coil units in Building E showed category III performance only. Open ceiling active chilled beams in Building A corresponded to category II requirements and ceiling panels for room conditioning in Building D showed superior Category I performance. Category II and III results with active chilled beams indicate that dedicated air distribution solution together with proper design and sizing is needed to reach category II.

We found that existing standards do not provide enough detailed questionnaire for the assessment of occupant dissatisfaction. Our results suggest that questionnaire could be an easier compliance assessment method compared to measurements, which need an expensive equipment and carefully selected measurement days. For the compliance assessment with the measurement, there is more guidance needed especially how to select relevant measurement conditions and locations for draught rate measurement. Future office buildings with open-plan layouts revealed to be demanding environments where careful air distribution design is needed in order to meet comfort requirements.

Author Contributions: J.K. conceived and designed the experiments. M.K. prepared agreements with the building owners, performed the measurements and analyzed the data. M.T. and J.K. helped to perform the data analysis. M.K., R.S., M.T., and J.K. wrote this paper. All authors have read and agreed to the published version of the manuscript.

Funding: This research was supported by the Estonian Centre of Excellence in Zero Energy and Resource Efficient Smart Buildings and Districts, ZEBE (grant 2014-2020.4.01.15-0016) funded by the European Regional Development Fund, by the programme Mobilitas Pluss (Grant No-2014-2020.4.01.16-0024, MOBTP88), by the European Commission through the H2020 project Finest Twins (grant No. 856602) and the Estonian Research Council grant (PSG409).

Acknowledgments: The authors are grateful for the provided cooperation of the building owners, questionnaire respondents for their time and the valuable help from Tallinn University of Technology graduate students.

Conflicts of Interest: The authors declare no conflict of interest.

\section{Nomenclature}

$\begin{array}{ll}A & \text { net floor area }\left(\mathrm{m}^{2}\right) \\ C_{r e s} & \text { respiratory convective heat exchange }\left(\mathrm{W} / \mathrm{m}^{2}\right) \\ D R & \text { draught rate }(\%) \\ & \text { evaporative heat exchange at the skin, when the person experiences a } \\ E_{c} & \text { sensation of thermal neutrality }\left(\mathrm{W} / \mathrm{m}^{2}\right) \\ E_{r e s} & \text { respiratory evaporative heat exchange }\left(\mathrm{W} / \mathrm{m}^{2}\right) \\ f_{c l} & \text { clothing surface area factor } \\ g & \text { solar radiation transmittance through window glass } \\ H & \text { heat loss }(\mathrm{W} / \mathrm{K}) \\ H_{d} & \text { dry heat loss }\left(\mathrm{W} / \mathrm{m}^{2}\right) \\ h_{c} & \text { convective heat transfer coefficient }\left[\mathrm{W} /\left(\mathrm{m}^{2} \times \mathrm{K}\right)\right] \\ \mathrm{HVAC} & \text { heating, ventilation, and air conditioning } \\ I_{c l} & \text { clothing insulation }\left[\left(\mathrm{m}^{2} \times \mathrm{K}\right) / \mathrm{W}\right] \\ \mathrm{ICQ} & \text { indoor climate questionnaire } \\ M & \text { metabolic rate }\left(\mathrm{W} / \mathrm{m}^{2}\right) \\ m t_{s k} & \text { mean skin temperature }\left({ }^{\circ} \mathrm{C}\right) \\ p_{a} & \text { water vapor partial pressure }(\mathrm{Pa}) \\ P M V & \text { predicted mean vote } \\ P P D & \text { predicted percentage dissatisfied }(\%) \\ R H & \text { relative humidity }(\%) \\ S D & \text { standard deviation } \\ \text { TABS } & \text { thermally active building systems }\end{array}$




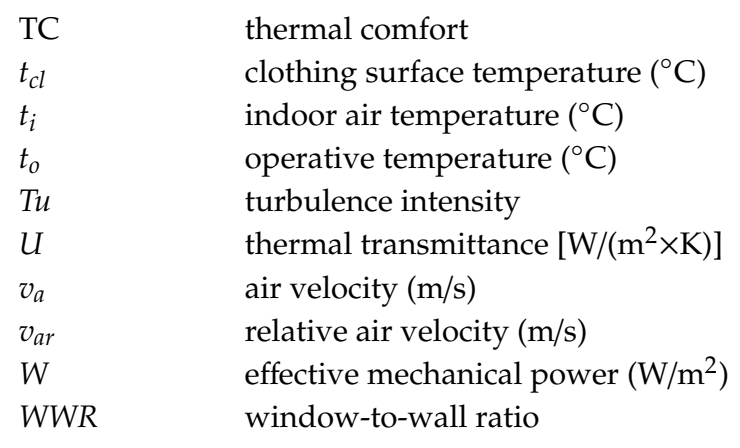

\section{Appendix A}

The ICQ form is for online survey is provided below.

1. Gender-( ) Female, ( ) Male

2. Age-( ) 18-25, ( ) 26-35, ( ) 36-45, ( ) 46-55, ( ) 56-65, ( ) 66+

3. Workstation-( ) Private office (max 3 people), ( ) Open office

4. Which amount of the workday you spend at your desk-( ) Whole workday, ( ) Half of the workday (up to 4-5 h), ( ) Few hours (max 1-2 h)

5. In which zone do you spend the most of your workday (1-n in picture)-( ) 1-n

6. How do you rate you thermal sensation (choose neutral if you do not want a change in temperature)-( ) Hot, ( ) Warm, ( ) Slightly warm, ( ) Comfortable, ( ) Slightly cool, ( ) Cool, ( ) Cold

7. How do you perceive odor intensity-( ) No odor, ( ) Weak, ( ) Moderate, ( ) Strong, ( ) Very strong, ( ) Unbearable

8. Would you prefer the room temperature to be-( ) Higher, ( ) Unchanged, ( ) Lower

9. Does the room lighting disturb working-( ) Yes, ( ) No

10. Does the sunlight disturb working- ( ) Yes, ( ) No

11. Please rate (room temperature is)-( ) Perfect, ( ) Good, ( ) Suitable, ( ) Unsuitable, ( ) Unbearable

12. Please rate (air quality is) - ( ) Perfect, ( ) Good, ( ) Suitable, ( ) Unsuitable, ( ) Unbearable

13. How do you perceive acoustic level (colleagues' speech and overall room acoustics) - ( ) Does not disturb at all, ( ) Rarely disturbs, ( ) Sometimes disturbs, ( ) Often disturbs, ( ) Disturbs all the time

14. How do you perceive other noise in your workplace-( ) Does not disturb at all, ( ) Rarely disturbs, ( ) Sometimes disturbs, ( ) Often disturbs, ( ) Disturbs all the time

15. Whether and how often have you experienced the following symptoms (eye dryness or irritation)-( ) Never, ( ) Rarely, ( ) Sometimes, ( ) Often, ( ) All the time

16. Whether and how often have you experienced the following symptoms (headache or fatigue)-( ) Never, ( ) Rarely, ( ) Sometimes, ( ) Often, ( ) All the time

17. Whether and how often have you experienced the following symptoms (nasal or throat dryness or irritation)-( ) Never, ( ) Rarely, ( ) Sometimes, ( ) Often, ( ) All the time

18. Whether and how often have you experienced the following symptoms (concentration problems)-( ) Never, ( ) Rarely, ( ) Sometimes, ( ) Often, ( ) All the time

\section{References}

1. Seppanen, O. Ventilation Strategies for Good Indoor Air Quality and Energy Efficiency. Int. J. Vent. 2008, 6, 297-306.

2. Yang, Z.; Ghahramani, A.; Becerik-Gerber, B. Building occupancy diversity and HVAC (heating, ventilation, and air conditioning) system energy efficiency. Energy 2016, 109, 641-649. [CrossRef]

3. Mathews, E.H.; Botha, C.P.; Arndt, D.C.; Malan, A.G. HVAC control strategies to enhance comfort and minimise energy usage. Energy Build. 2001, 33, 853-863. [CrossRef]

4. Simmonds, P. The Utilization of Optimal-Design and Operation Strategies in Lowering the Energy-Consumption in Office Buildings. Renew. Energy 1994, 5, 1193-1201. [CrossRef]

5. Guo, W.; Zhou, M. Technologies toward thermal comfort-based and energy-efficient HVAC systems: A review. In Proceedings of the 2009 IEEE International Conference on Systems, Man and Cybernetics, San Antonio, TX, USA, 11-14 October 2009; pp. 3883-3888.

6. Fanger, P.O.; Christensen, N.K. Perception of draught in ventilated spaces. Ergonomics 1986, 29, $215-235$. [CrossRef] [PubMed] 
7. Shahrestani, M.; Yao, R.M.; Cook, G.K. Decision Making for HVAC\&R System Selection for a Typical Office Building in the UK. Ashrae Trans. 2012, 118, 222-229.

8. Nemethova, E.; Stutterecker, W.; Schoberer, T. Thermal Comfort and HVAC Systems Operation Challenges in a Modern Office Building-Case Study. Sel. Sci. Pap. J. Civ. Eng. 2016, 11, 103-114. [CrossRef]

9. Shahzad, S.S.; Brennan, J.; Theodossopoulos, D.; Hughes, B.; Calautit, J.K. Energy Efficiency and User Comfort in the Workplace: Norwegian Cellular vs. British Open Plan Workplaces. Energy Procedia 2015, 75, 807-812. [CrossRef]

10. Choi, J.H.; Loftness, V.; Aziz, A. Post-occupancy evaluation of 20 office buildings as basis for future IEQ standards and guidelines. Energy Build. 2012, 46, 167-175. [CrossRef]

11. Karjalainen, S. Thermal comfort and gender: A literature review. Indoor Air 2012, 22, 96-109. [CrossRef]

12. Schellen, L.; Loomans, M.G.L.C.; de Wit, M.H.; Olesen, B.W.; Lichtenbelt, W.D.V. The influence of local effects on thermal sensation under non-uniform environmental conditions-Gender differences in thermophysiology, thermal comfort and productivity during convective and radiant cooling. Physiol. Behav. 2012, 107, 252-261. [CrossRef] [PubMed]

13. Rupp, R.F.; Vasquez, N.G.; Lamberts, R. A review of human thermal comfort in the built environment. Energy Build. 2015, 105, 178-205. [CrossRef]

14. Pfafferott, J.U.; Herkel, S.; Kalz, D.E.; Zeuschner, A. Comparison of low-energy office buildings in summer using different thermal comfort criteria. Energy Build. 2007, 39, 750-757. [CrossRef]

15. Hens, H.S.L.C. Thermal comfort in office buildings: Two case studies commented. Build. Environ. 2009, 44, 1399-1408. [CrossRef]

16. Kolarik, J.; Toftum, J.; Olesen, B.W. Operative temperature drifts and occupant satisfaction with thermal environment in three office buildings using radiant heating/ cooling system. In Proceedings of the Healthy Buildings Europe 2015, Eindhoven, The Netherlands, 18-20 May 2015.

17. Griefahn, B.; Kunemund, C. The effects of gender, age, and fatigue on susceptibility to draft discomfort. J. Therm. Biol. 2001, 26, 395-400. [CrossRef]

18. Maykot, J.K.; Rupp, R.F.; Ghisi, E. A field study about gender and thermal comfort temperatures in office buildings. Energy Build. 2018, 178, 254-264. [CrossRef]

19. Maula, H.; Hongisto, V.; Ostman, L.; Haapakangas, A.; Koskela, H.; Hyona, J. The effect of slightly warm temperature on work performance and comfort in open-plan offices - a laboratory study. Indoor Air 2016, 26, 286-297. [CrossRef]

20. Wang, Z.; de Dear, R.; Luo, M.H.; Lin, B.R.; He, Y.D.; Ghahramani, A.; Zhu, Y.X. Individual difference in thermal comfort: A literature review. Build. Environ. 2018, 138, 181-193. [CrossRef]

21. Kim, J.; Zhou, Y.X.; Schiavon, S.; Raftery, P.; Brager, G. Personal comfort models: Predicting individuals' thermal preference using occupant heating and cooling behavior and machine learning. Build. Environ. 2018, 129, 96-106. [CrossRef]

22. Pazhoohesh, M.; Zhang, C. A satisfaction-range approach for achieving thermal comfort level in a shared office. Build. Environ. 2018, 142, 312-326. [CrossRef]

23. Enescu, D. A review of thermal comfort models and indicators for indoor environments. Renew. Sustain. Energy Rev. 2017, 79, 1353-1379. [CrossRef]

24. Laftchiev, E.; Nikovski, D. An IoT system to estimate personal thermal comfort. In Proceedings of the 2016 IEEE 3rd World Forum on Internet of Things (WF-IoT), Reston, VA, USA, 12-14 December 2016; pp. 672-677.

25. Ghahramani, A.; Castro, G.; Karvigh, S.A.; Becerik-Gerber, B. Towards unsupervised learning of thermal comfort using infrared thermography. Appl. Energy 2018, 211, 41-49. [CrossRef]

26. Jung, W.; Jazizadeh, F. Human-in-the-loop HVAC operations: A quantitative review on occupancy, comfort, and energy-efficiency dimensions. Appl. Energy 2019, 239, 1471-1508. [CrossRef]

27. Shi, J.; Yu, N.P.; Yao, W.X. Energy efficient building HVAC control algorithm with real-time occupancy prediction. In Proceedings of the 8th International Conference on Sustainability in Energy and Buildings, Turin, Italy, 11-13 September 2017.

28. Thalfeldt, M.; Pikas, E.; Kurnitski, J.; Voll, H. Facade design principles for nearly zero energy buildings in a cold climate. Energy Build. 2013, 67, 309-321. [CrossRef]

29. Kähkönen, E. Draught, Radiant Temperature Asymmetry and Air Temperature - a Comparison between Measured and Estimated Thermal Parameters. Indoor Air 1991, 1, 439-447. [CrossRef] 
30. Kiil, M.; Mikola, A.; Thalfeldt, M.; Kurnitski, J. Thermal comfort and draught assessment in a modern open office building in Tallinn. E3S Web Conf. 2019, 111, 02013. [CrossRef]

31. Rhee, K.N.; Olesen, B.W.; Kim, K.W. Ten questions about radiant heating and cooling systems. Build. Environ. 2017, 112, 367-381. [CrossRef]

32. Saber, E.M.; Tham, K.W.; Leibundgut, H. A review of high temperature cooling systems in tropical buildings. Build. Environ. 2016, 96, 237-249. [CrossRef]

33. Schellen, L.; Loomans, M.G.L.C.; de Wit, M.H.; Olesen, B.W.; Lichtenbelt, W.D.V.M. Effects of different cooling principles on thermal sensation and physiological responses. Energy Build. 2013, 62, 116-125. [CrossRef]

34. Maula, H.; Hongisto, V.; Koskela, H.; Haapakangas, A. The effect of cooling jet on work performance and comfort in warm office environment. Build. Environ. 2016, 104, 13-20. [CrossRef]

35. Gao, S.; Wang, Y.A.; Zhang, S.M.; Zhao, M.; Meng, X.Z.; Zhang, L.Y.; Yang, C.; Jin, L.W. Numerical investigation on the relationship between human thermal comfort and thermal balance under radiant cooling system. Energy Procedia 2017, 105, 2879-2884. [CrossRef]

36. Cen, C.; Jia, Y.H.; Liu, K.X.; Geng, R.X. Experimental comparison of thermal comfort during cooling with a fan coil system and radiant floor system at varying space heights. Build. Environ. 2018, 141, 71-79. [CrossRef]

37. Kolarik, J.; Toftum, J.; Olesen, B.W.; Jensen, K.L. Simulation of energy use, human thermal comfort and office work performance in buildings with moderately drifting operative temperatures. Energy Build. 2011, 43, 2988-2997. [CrossRef]

38. Fonseca, N. Experimental study of thermal condition in a room with hydronic cooling radiant surfaces. Int. J. Refrig. 2011, 34, 686-695. [CrossRef]

39. Li, R.L.; Yoshidomi, T.; Ooka, R.; Olesen, B.W. Field evaluation of performance of radiant heating/cooling ceiling panel system. Energy Build. 2015, 86, 58-65. [CrossRef]

40. Saber, E.M.; Iyengar, R.; Mast, M.; Meggers, F.; Tham, K.W.; Leibundgut, H. Thermal comfort and IAQ analysis of a decentralized DOAS system coupled with radiant cooling for the tropics. Build. Environ. 2014, 82, 361-370. [CrossRef]

41. Chiang, W.H.; Wang, C.Y.; Huang, J.S. Evaluation of cooling ceiling and mechanical ventilation systems on thermal comfort using CFD study in an office for subtropical region. Build. Environ. 2012, 48, 113-127. [CrossRef]

42. Mustakallio, P.; Bolashikov, Z.; Kostov, K.; Melikov, A.; Kosonen, R. Thermal environment in simulated offices with convective and radiant cooling systems under cooling (summer) mode of operation. Build. Environ. 2016, 100, 82-91. [CrossRef]

43. Cehlin, M.; Karimipanah, T.; Larsson, U.; Ameen, A. Comparing thermal comfort and air quality performance of two active chilled beam systems in an open-plan office. J. Build. Eng. 2019, 22, 56-65. [CrossRef]

44. Kim, T.; Kato, S.; Murakami, S.; Rho, J. Study on indoor thermal environment of office space controlled by cooling panel system using field measurement and the numerical simulation. Build. Environ. 2005, 40, 301-310. [CrossRef]

45. Fredriksson, J.; Sandberg, M.; Moshfegh, B. Experimental investigation of the velocity field and airflow pattern generated by cooling ceiling beams. Build. Environ. 2001, 36, 891-899. [CrossRef]

46. Rhee, K.N.; Shin, M.S.; Choi, S.H. Thermal uniformity in an open plan room with an active chilled beam system and conventional air distribution systems. Energy Build. 2015, 93, 236-248. [CrossRef]

47. Koskela, H.; Haggblom, H.; Kosonen, R.; Ruponen, M. Air distribution in office environment with asymmetric workstation layout using chilled beams. Build. Environ. 2010, 45, 1923-1931. [CrossRef]

48. Indraganti, M.; Ooka, R.; Rijal, H.B. Thermal comfort in offices in summer: Findings from a field study under the 'setsuden' conditions in Tokyo, Japan. Build. Environ. 2013, 61, 114-132. [CrossRef]

49. De Vecchi, R.; Candido, C.; de Dear, R.; Lamberts, R. Thermal comfort in office buildings: Findings from a field study in mixed-mode and fully-air conditioning environments under humid subtropical conditions. Build. Environ. 2017, 123, 672-683. [CrossRef]

50. Azad, A.S.; Rakshit, D.; Wan, M.P.; Babu, S.; Sarvaiya, J.N.; Kumar, D.E.V.S.K.; Zhang, Z.; Lamano, A.S.; Krishnasayee, K.; Gao, C.P.; et al. Evaluation of thermal comfort criteria of an active chilled beam system in tropical climate: A comparative study. Build. Environ. 2018, 145, 196-212. [CrossRef]

51. He, Y.D.; Li, N.P.; Huang, Q. A field study on thermal environment and occupant local thermal sensation in offices with cooling ceiling in Zhuhai, China. Energy Build. 2015, 102, 277-283. [CrossRef] 
52. CEN EN 15251:2007. European Committee for Standardization, Indoor Environmental Input Parameters for Design and Assessment of Energy Performance of Buildings Addressing Indoor Air Quality, Thermal Environment, Lighting and Acoustics; European Committee for Standardization: Brussels, Belgium, 2007.

53. Fanger, P.O. Thermal Comfort, Analysis and Applications in Environmental Engineering; Danish Technical Press: Manhattan, KS, USA, 1970.

54. CEN EN 16798-1:2019. Energy Performance of Buildings_Ventilation for Buildings_Part 1: Indoor Environmental Input Parameters for Design and Assessment of Energy Performance of Buildings Addressing Indoor Air Quality, Thermal Environment, Lighting and Acoustics-Module M1-6; European Committee for Standardization: Brussels, Belgium, 2019.

55. ISO 7726:1998. Ergonomics of the Thermal Environment-Instruments for Measuring Physical Quantities; International Organization for Standardization: Geneva, Switzerland, 1998.

56. Dantec Dynamics. ComfortSense specification; Dantec Dynamics A/S, A Nova Instruments Company: Denmark, Skovlunde, 2019; Available online: http://www.dantecdynamics.jp/docs/products-and-services/thermalcomfort/PI264_ComfortSense.pdf (accessed on 5 June 2019).

57. Ministry of Economic Affairs and Communications. Estonian Regulation No 258: Minimum Requirements for Energy Performance. Riigi Teataja 2007, 72, 445.

58. Thermal Comfort. Innova AirTech Instruments A/S. 2002. Available online: http://www.labeee.ufsc.br/sites/ default/files/disciplinas/Thermal\%20Booklet.pdf (accessed on 10 July 2019).

59. CEN EN 15726:2011. Ventilation for Buildings-Air Diffusion-Measurements in the Occupied Zone of Air-Conditioned/Ventilated Rooms to Evaluate Thermal and Acoustic Conditions; European Committee for Standardization: Brussels, Belgium, 2011.

60. ISO 7730:2005. Ergonomics of the Thermal Environment-Analytical Determination and Interpretation of Thermal Comfort Using Calculation of the PMV and PPD Indices and Local Thermal Comfort Criteria; International Organization for Standardization: Geneva, Switzerland, 2005.

61. Google. Google Forms. Google Inc., Mountain View (CA), USA. 2019. Available online: https://www.google. com/forms/about/ (accessed on 1 July 2019).

62. EMHI. Observation Data. Estonian Weather Service: Tallinn, Estonia. 2019. Available online: https://www.ilmateenistus.ee/ilm/ilmavaatlused/vaatlusandmed/tunniandmed/?lang=en (accessed on 15 September 2019).

63. Wang, J.Y.; Wang, Z.; de Dear, R.; Luo, M.H.; Ghahramani, A.; Lin, B.R. The uncertainty of subjective thermal comfort measurement. Energy Build. 2018, 181, 38-49. [CrossRef] 